University of Louisville

ThinkIR: The University of Louisville's Institutional Repository

Electronic Theses and Dissertations

1938

\title{
Heat transfer studies of a hydrocarbon oil.
}

W. R. Barnes

University of Louisville

Follow this and additional works at: https://ir.library.louisville.edu/etd

Part of the Chemical Engineering Commons

\section{Recommended Citation}

Barnes, W. R., "Heat transfer studies of a hydrocarbon oil." (1938). Electronic Theses and Dissertations. Paper 1670.

https://doi.org/10.18297/etd/1670

This Master's Thesis is brought to you for free and open access by ThinkIR: The University of Louisville's Institutional Repository. It has been accepted for inclusion in Electronic Theses and Dissertations by an authorized administrator of ThinkIR: The University of Louisville's Institutional Repository. This title appears here courtesy of the author, who has retained all other copyrights. For more information, please contact thinkir@louisville.edu. 


\title{
UNI VRRSITY OF LOUIBVICTS
}

\section{HEAT TRANSTIRR STUDIIS OP A HYOROCARBOI OII}

\author{
A Thesis: \\ Bubmitted to the Fraculty \\ of the Graduate School of the University of Louisville \\ In Partial Furfillment of the \\ Requirements for the Degree of \\ Master of Chemical Engineering
}

Department of Chemical Ingineering

By

w! ${ }^{S 0^{n}} \rho^{S}{ }_{\text {Barnes }}^{S}$ 
Milson R. Barnes

WEAT TRAISFER

STUDIES OF A HYDOCARBON OIL

Director:

Approved by

Reading Committee:
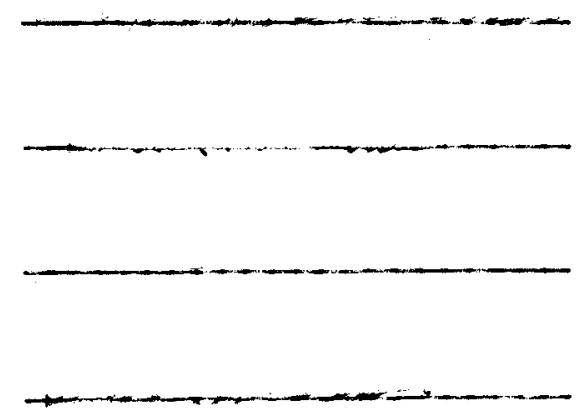

Date:

Nay 17,1938 
TABLEOF CONTINT

Page

Iist of Tables

3

List of Curres

3

Liat of Illustrations

3

List of Symbols

4

Acknowledgment

6

I. Introduction

7

II. Theoretical

11

III. Apparatus

14

IV. Date and Results

35

v. Conclusions 66

VI. Bibllography

71 
I I T OF TA BIES

Page

Table I. Physical Properties of Rocene 33

Table II. Heat Transfer Data 37

I I T OF C URVES

Curve I. Focene Viscosity Variation with Temperature Change

34

Curve II. Cooling Data Correlation

65

Curve III. Grouping and Comparison of

Heat Transfer Data

L I S T O F I L IUSTRATIONS

Figure I. Heat Erchanger ithout

Insulation

Figure II. Heat Fxchanger With Insulation

$$
\text { and Additions }
$$

Figure III. Amonia Compressor 


\section{LIST OP SYMBOLS}

Symbol

A

$c_{p}$

D

$\mathbf{f}$

8

G

h

k

I

II

dII

dP

Q

$t_{1}$

$t_{2}$
Quantity

Heat transfer surface

Specific heat

Diameter of pipe

Friction factor

Acceleration due to gravity

Hase relocity

Heat tranafer coefficient

Thermal conductivity

Length of path of heat

conduction

Iongth of test section

Differential length of pipe

Differential pressure drop

$$
\text { due to friction }
$$

quantity of heat transferred

Fluid entrance temperature

Fluid exit temperature
Units

sq.ft.

B.t.u./(2b.) (deg.F.)

ft.

none

$\mathrm{ft.} / \mathrm{hr} .^{2}$

$1 b . /\left(h r_{.}\right)\left(8 q . f t_{.}\right)$

B.t.u./(hr.)

$\left(\mathrm{gq}, f t_{0}\right)(d e g, f)$

B.t.u. $/(\mathrm{hx}$.

$\left(s q . f t_{.}\right)\left(d e g . F / f t_{.}\right)$ 


\section{IIST OF EYMBIS (Concluded)}

Symbol

Quantity

Units

$t_{3}$

Refrigerant entrance temperature

$\operatorname{deg} \cdot \mathrm{F}$

$t_{4}$

Refrigerant exist temperature

$\operatorname{deg} \cdot F$

v

Velocity of fluid in pipe It./hr.

w Weight rate of $f 10 \pi$

Ib./mr.

2

Tiscosity

Centipoise

$\Delta t$

Temperature difference

$\operatorname{deg} \cdot F$

Deneity of fluid

1b./cu.ft.

V1scosity of film

1b./(hr.) (ft.)

Bulk Viscosity $1 b_{\circ} /\left(h x_{\bullet}\right)\left(f t_{\bullet}\right)$

Symbols are according to the system recommended by the Council of the American Institute of Chemical Ingineers. 
ACKMOWLEDGMENT

The author of this thesis

wishes to acknowledge

the kind aid and helpful suggestions of

Dr. R. C. Brnst,

who directed this research. 
I. INTRODUCTION 
This study of heat transfer of a hydrocarbon oil was made for the investigation of cooling phenomena In the upper viscous and lower turbulent range. All data reported or discussed in this dissertation are cooling data on "Bocene", a refined kerosene. The primary object of the research was the observation of the characteristics in the cooling of a hydrocarbon 011 in the eritical rogion.

Previous workers in the same field have reported cooling data correlated in numerous ways. Howerer, it was found that the most satisfactory correlation of the date obtained in this research was by means of an equation of the Dittus and Boelter type. (I). Nlthough this type of equation does not represent the date perfectly, it does give a far better presentation of the results than other methods attempted.

The sudies reported in this presentation were made on a liquid heat exchanger designed by Browne and Finger (2) and constructed by Browne (3) and Donaher (4). In order to attain the temperatures desired, It was found necessary to install a three-quarter ton ice machine for the cooling of the 
refrigerant 11quid. In the installation of this refrigeration unit, eeveral minor changes were made in the original piping layout.

As the heat exchanger was operated and lower temperatures were sought, it was found necessary to resort to insulation for the successful maintenance of relatively $10 \mathrm{r}$ temperatures. The range of pipe temperatures reported raried from $60^{\circ} \mathrm{F}$ to $20^{\circ} \mathrm{F}$. Consequently, it followed that the test liquid temperatures were higher than the corresponding pipe temperatures. It was also logical that the refrigerant liquid temperature be considerably fower than the pipe temperatures.

In the insulation of the exchanger, cork was used for the refrigerant reservoir and hair felt for the piping.

All temperatures were measured by means of thermocouples read with a type " $\mathrm{K}$ " potentiometer. The use of such an arrangement made possible the reading of temperature differences to three significant figures. Whether such accuracy was justified in all cases is problematical. However, this accuracy Irequently made data haring small temperature differences valuable. 


\begin{abstract}
All the date presented in this sudy were obtained using "Iocene" as both test liquid and cooling liquid.
\end{abstract}


II. THEORETICAI 
An examination of the literature for a means of correlating heat transfer data led to the conclusion that the most satisfactory method would be the use of dimensionlese groups $(4-16)$. It was decided to use an equation of the type suggested by Dittus and Boelter:

$$
\frac{h D}{k}=0.026 \frac{D G}{\mu}^{0.8}{\frac{c_{p} \mu}{k}}^{0.3}
$$

This equation is recomended by them for cooling data

since an equation of this type can be converted by proper mathematical manipulation into types that are used for both turbulent and viscous flow, the use of this type of equation followed (I6).

The equation consists of the following dimensionless groups:

$$
\begin{array}{ll}
\text { Prand tl number } & c \mu / k \\
\text { Ireselt Number } & h D / k \\
\text { Reynolds Number } & D G / \mu
\end{array}
$$

The Prandil number containg terms that are properties only. Since this fact is true, it would seem that the Prand tl number would be of no significance except in cases in which the properties have a marked vartation. Furthermore it would seem logical that 
the greatest property variation would occur at the film. Hence, in the correlation of these data an average film viscosity was used. The film temperature was found by taking the arithmetic mean temperature between that of the pipe and the arerage test liquid temperature (16).

The Iusselt number contains only conductivity terms and thereby indicates its ralue in the study of heat transfer through films.

The Reynolds number is a flow term and would seem to become more important as turbulence is increased. Howerer, since it is concerned with flow rather than with heat conduction or property change, the use of a viscosity at an arerage test liquid temperature would seem to coincide with the purpose of the group.

Since this equation contains a flow group, a conduction group, and a property change group, all the activity occurring in both the viscous and turbulent regions should be adequately expressed. 
III. APPARATUS 
FIGURE I.

HEAT RXCHANGER WITHOUT INSULATION 


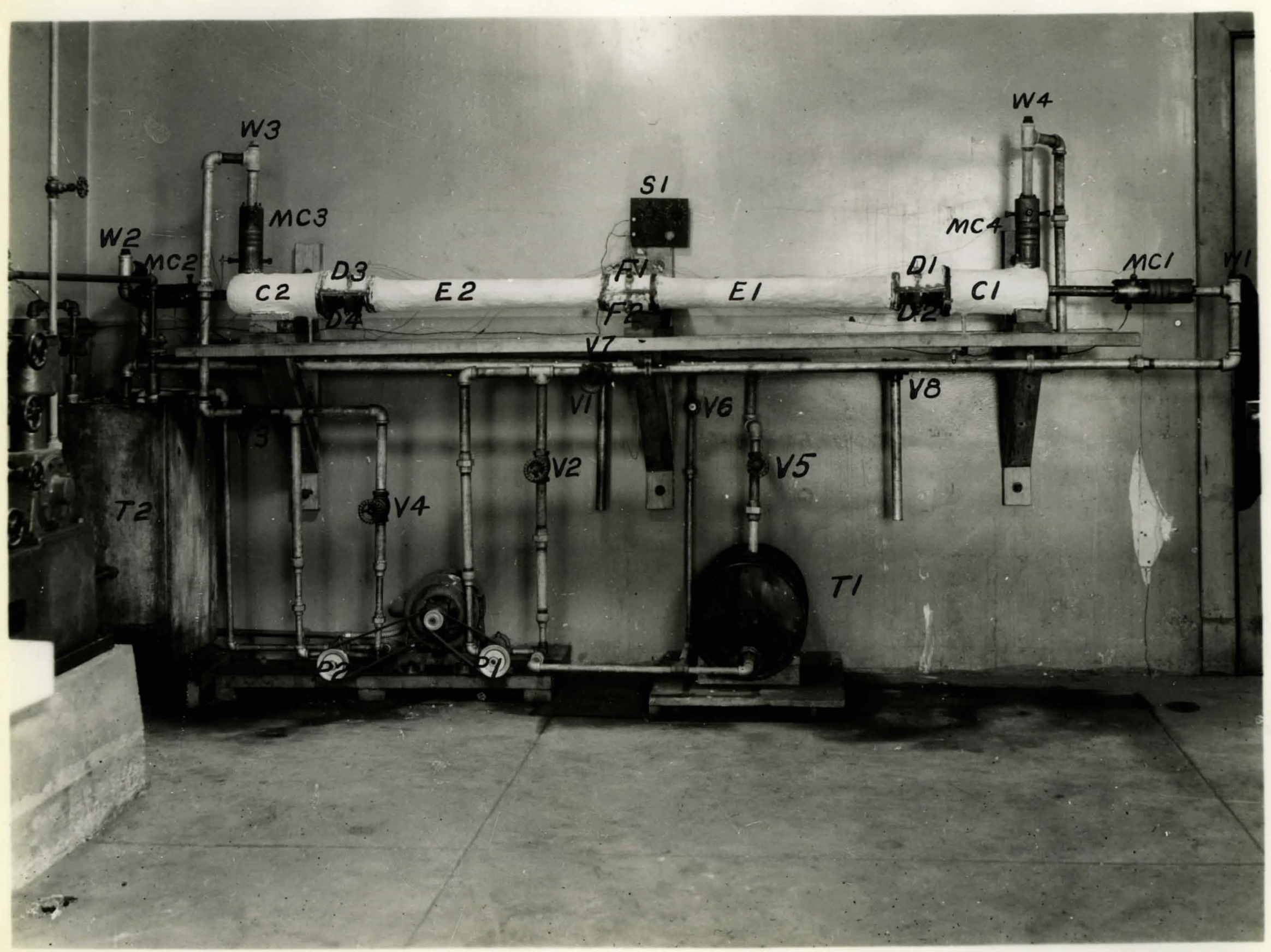


FIGURE II.

HISAT IRXCHANGER WITH INSULATION AND ADDITIONS 


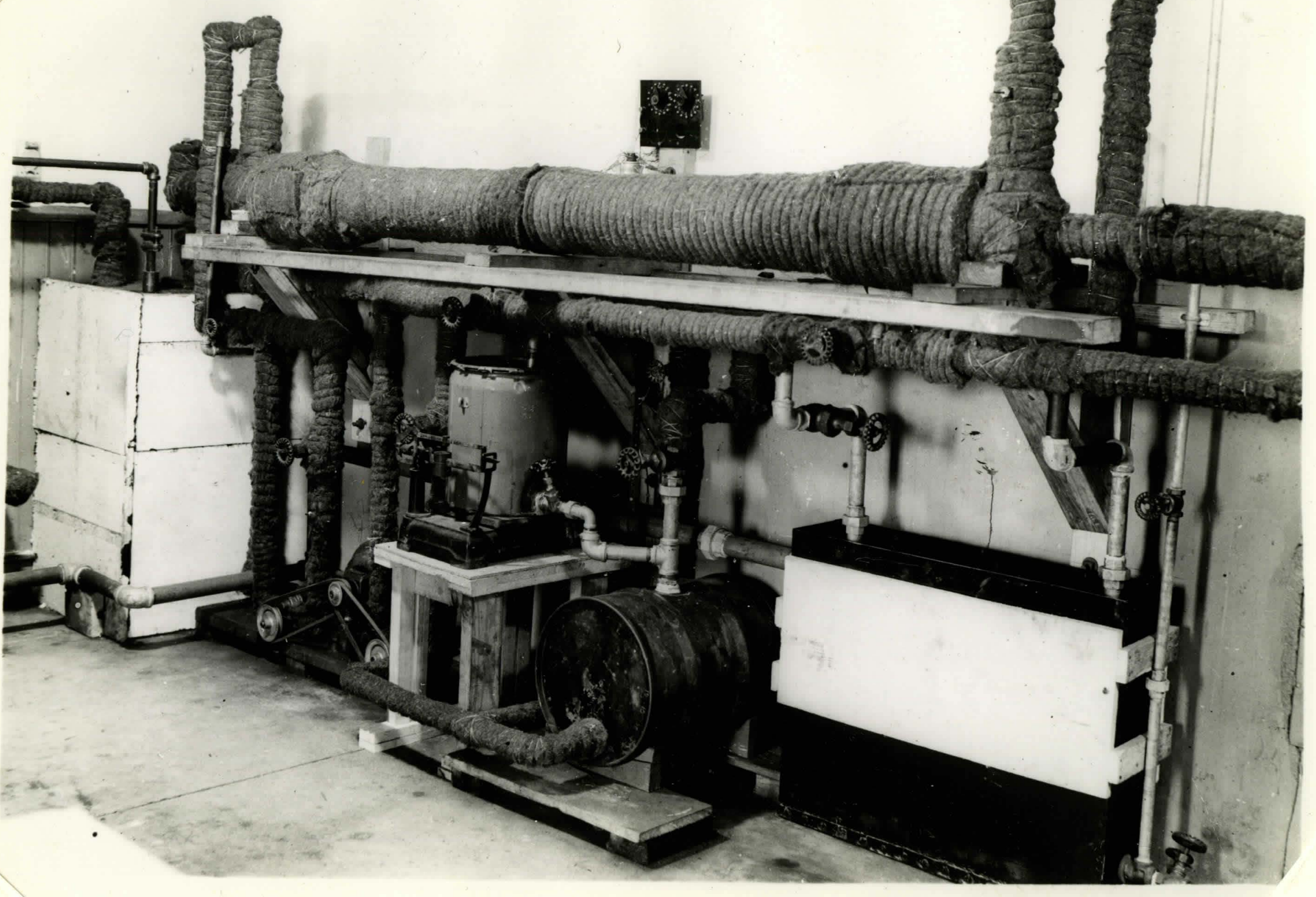


FIGURE III. ARIONIA COMPRIESSOR 


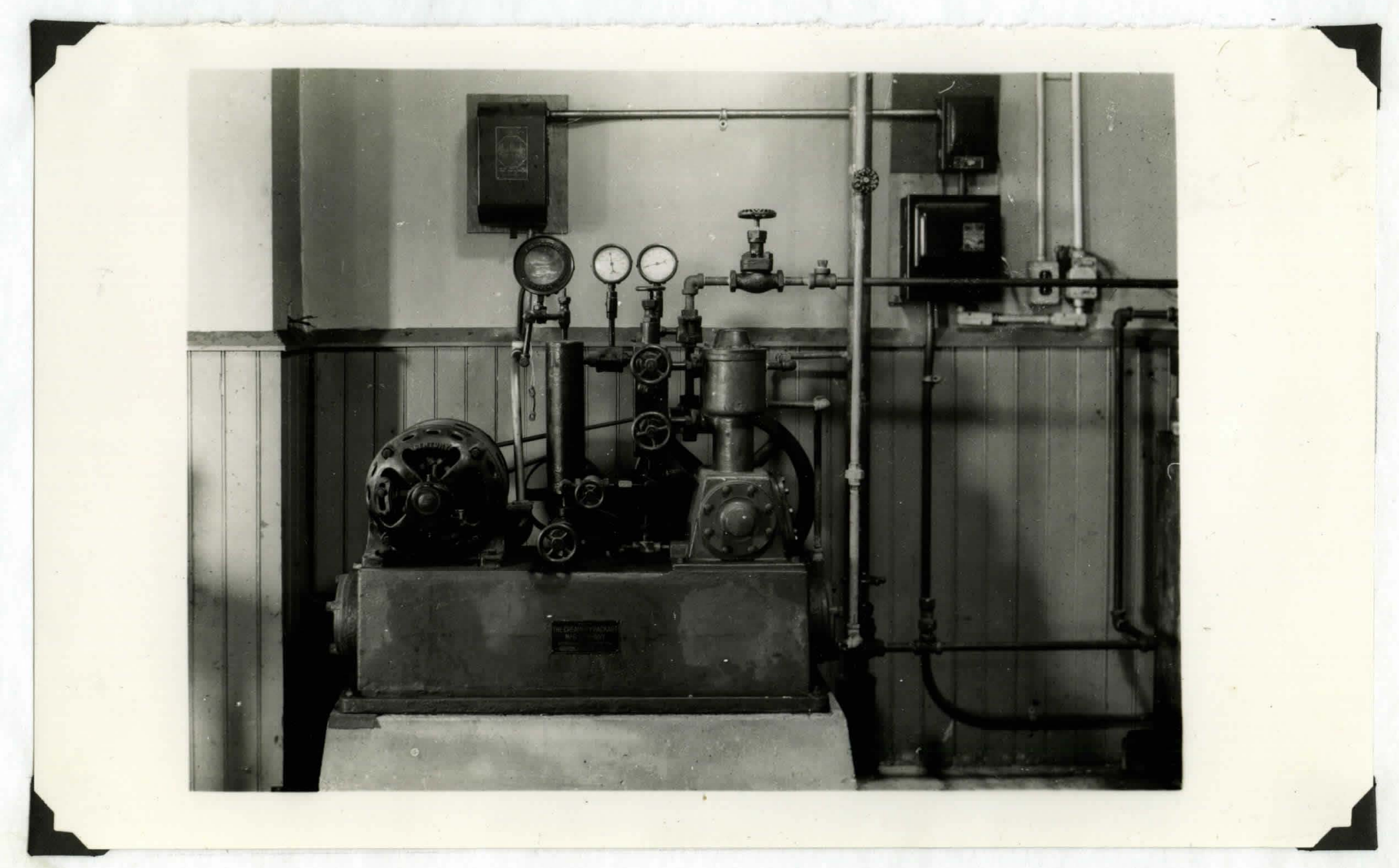


With the apparatus used in this investigation, the means are provided for the determination of temperatures and rates of flow in order that the heat transfer coefficients and various related dimensionless groups may be calculated. The equipment consists of the heat exchanger proper and the accessories.

The entire apparatus is shown in Figures I.. II.. and III., pages 15,17 , and 19, and is described with reference to the figures in the following discussion.

HEAT EXCHATGER

The heat exchanger proper includes the test section, the calming and mixing chambers, and the thermocouples. The test section consists of a standard one inch brass pipe within a cast iron shell. This brass pipe is a single length 9 feet, 6 inches long. The test section includes a calming section of 23 inches, a test length of 6 feet, and an exit section of 19 inches. The cast iron annular shell is composed of an inlet and outlet section for the refrigerant, $C I$ and $C 2$; and several sleeves. Sections $\mathrm{E} 1$ and $\mathrm{E} 2$ are two 30 inch sleeves. The 
sections marked $D$ and $F$ are split sleeves through which the thermocouple junctions are installed. The calming aections installed in the inlet and outlet sections of the refrigerant system are for the purpose of proventing turbulence in the sicinity of the thermocouple junctions at the pipe ende. These calming sections also bring about atreamine flow of the refrigerant after it has passed through the mixing chambers. The purpose of the calming section is the elimination of the turbulence of the liquid after passage through the mixing chamber. The calming section has a crose made of sheet copper, inserted in the brass pipe between the test section and the mixing chamber at the entrance end of the teat liquid sy s tem.

The mixing chambers consist of slotted copper plates and steel collars bolted together. The mixing chambers in the teat line, YC 1 and LC 2, and in the refrigerant line, yC 3 and 4 , effect a mixing so that an average temperature of the liquid immediately of ter the chamber may be obtained by a single thermocouple placed in the center of the stream. In order that heat transfer may be reduced to a minimum between the refrigerant and the test liquid 
in the refrigerant inlet and outlet sections inner steel sleeves are provided. These sleeves forming an annular space around the ends of the brass pipe extend to the centers of the cast iron sleeves, D 1, D 2, D 3, and D 4. This annular space around each end of the brass pipe is packed with rock wo01. In order that undesirable conduction between the cast iron shell and the test section might be minimized, asbestos strips are placed between the surfaces making contact. Such conduction, hovever, 18 of minor importance since the areas of contact are small and relatirely distant from the teat section. For the measurement of temperatures, sixteen thermocouples are installed in the heat exchanger. One thermocouple is located in each of the four mixing chambers and twelve are attached to the brass test section. Those couples fastened to the brass pipe are arranged in the following order: four thermocouples ninety degrees apart at each end and at the center of the test section. The thermocouples are made of No. 28 B \& $S$ gage iron and constantan wires welded together at one end and led to a cold junction behind the heat exchanger. From the cold junction 
connection is made to two dials by means of copper 1eads. The dials have sixteen terminals so that any thermocouple of the group may be connected to the potentiometer with a proper dial setting.

The thermocouples are installed in the mixing chambers through one-eighth inch copper tubing. centered in one-half inch steel bolts. These functions are located in the center of the liquid stream. The copper tubing extending from the bolts protects the Junction and holds it in the proper position.

The thermocouples for measuring the pipe temperature pass through copper tubing within one-half inch steel bolts in the split sleeves. Fach junction is soldered to the pipe at one end of a one-sixteenth inch by one inch slot cut in the pipe. The slots are filled with litharge and glycerine cement, and the surface smoothed to conform with the surface of the pipe.

ACCISSORIJS

Reservoirs are provided for the test and refrigerant liquids. The test liquid reservoir, 1 , is a ten-gallon teel arum placed in a horizontal position. A by-pass line around this reservolr is 
provided 80 that a control of the teat liquid temperature can be mintained. The refrigerant reservoir is a rectangular tank, T 2, having a capacity of about thirty gallons. The expansion colls of the ammonia compressor are located in this tank.

Originally the rate of flow was determined by means of an open tank into which the test liquid was allowed to flow for a measured amount of time with subsequent weighing of the collected liquid. However, it was found with the attaimment of temperatures even a few degrees below room temperature that this method of rate determination added too much heat to the system. In order to correct this fault a fire gallon covered tank was insulated with hair felt and mounted on a small platform scale. This arrangement is shown in Figure II.; page 17. The tank vas provided with an exit line near the bottom. The exit line containing a ralve emptied into an up-turned one-inch elbow that lod to the test liquid reservoir, T 1. A line from the three-way valve, V 7, extended through the cover of this tank in such a way that it in no way hindered the vertical movement of the tank on the platform scale. Heans of this 
installation the test liquid could be collected over a measured period of time, weighed, and returned to the system without the introduction of a too great amount of heat.

The test Iiquid is taken from the return line by means of the three-way valve, $V$. In the refrigerant line a similar three-way valve, $V$, is provided. The period of time over which the test I1quid wes collected was measured with a stop watch. This period varied from thirty to sixty seconds. Two pumps, $P 1$ and $P 2$, are provided for the circulation of the test and refrigerant liquids. $P 1$ is in the test liquid line, and $P 2$ is in the refrigerant line. These pumps are bronze gear pumps, having a rated capacity of six gallons per minute at a speed of 1000 R.P.M. A constant-speed, electric motor drives the pumps.

The rate of flow of the two liquids is controlled by means of the ralres, $\nabla 1, V 2, V 3$, and V 4. Valres $V 2$ and $V 4$ are in the by-pass IInes. A three-quarter-ton ammonia compresor was installed for the attainment of lower temperatures. The expansion coils of the compressor were located in the refrigerant reservolr. The refrigeration was controlled mamally by means of the adjustment of a 
needle-point expansion valve in the liquid ammonia Iine.

As a means of checking the thermocouple reedings, four thermometer wells are provided, 1 , W. 3, and 4. The rells are made of quarter-inch copper tubing plugged at one end and sealed in a drilled one-inch atandard cast-iron plug.

The thermocouple readings were taken with a Leads and Horthrup Type $\mathrm{K}$ potentiometer and a wall galvanometer. In order that vibration of the galvanometer be reduced to a minimum, it was mounted on a large concrete slab supported by four rubber cushions.

It was found very early in the operation of the heat exchanger that temperatures oven a few degrees below room temperature could not be reached and held with any success without the use of insulation. At first the test section alone was insulated; howerer, with operation at lower temperatures, it was found necessary to corer the entire apparatus. The refrigerant reservoir was covered with sheet-cork and Celotex. A layer of asbestos fiber mixed with plaster of paris and water was molded around the cast iron 
shell containing the test section in order that this section might be brought more nearly to a uniform size. The teat section was then covered with two inches of hair felt. The rest of the heat exchanger was covered with a one-inch thickness of hair felt.

With the insulation of the entire heat exchanger, it was found that the time required to bring the apparatus to equilibrium was increased greatly because of the lower temperatures attained. In order to shorten this time as well as to economire on the use of the refrigerant stored in the refrigerant reservoir, it was decided to install a cooling bank in the test liquid line. Thi s bank conbists of six 1-inch pipes between two headers. This additional piece of apparatus was placed in the line leading to the test section as is shown in Figure II., page 17. The installation was accomplished by instaling two tees with a valve between them in the test liquid line. Connection was made between the tees and the ends of the headers. A valve was also placed in the entrance line leading to the bank. This bank of pipes was placed in a galvanized iron 
tank to which a water connection was made at the bottom and an overflow drain connection made at the top. With this arrangement city water could be used for cooling prior to the circulation of the refrigerant.

OPRRATION

In the preparation of the heat exchanger for a run, the operation differs somewhat from its operation after equilibrium has been reached and thermocouple readings have been taken. Before the refrigerant is circulated, the test liquid is circulated and allowed to pass through the cooling bank. After the teet liquid has been cooled as mach as possible by means of the cooling bank, it is bypassed across the bank, and the refrigerant circulation begun. In the normal operation of the heat exchanger the pump, $P$ 1, draws the test liquid from the reservoir, $T$ 1, Valvea, $V 1$ and $V 2$, control the rate of flow. The liquid then passes to the mixing chamber, MC 1, where its temperature is measured. From the mixing chamber the liquid goes through the test section and then to the mixing chumber, MC 2 , where the temperature is again measured. The liquid 
then passes to either valves, V $5, \nabla 6$, or $\nabla 7$. $\nabla 7$ is the three-way valve which is used to divert the liquid for rate of flow determinations. V 6 is a valve in the by-pess line around the test liquid reservoir. Valves, $V 5$ and $V 6$, are both used in regulation of the quantity of liquid by-pessing the test liquid reservoir.

In the refrigerant aystem, the liquid is taken from the refrigerant by pump, $P 2$, and then passed, with the rate of flow controlled by valves, V 3 and $V$, to the mixing chamber, $M C$. In the mixing chamber the temperature is measured. The liquid then passes through the annular space around the test section and to mixing chamber, MC 4. The temperature is again determined and the liquid returned to the refrigerant reservolr, T 2 .

Before any data are taken on the apparatus. the refrigerant and test liquids are circulated until the desired temperatures are obtained and the apparatus has come to equilibrium. Equilibrium conditions are attained when the refrigerant and test liquid entrance temperatures have become constant. When the apparatus had come to equilibrium, the cold junctions of the thermocouples were brought 
to $32^{\circ} \mathrm{F}$. in an ice bath. The potentiometer circult was balanced, and the thermocouple reading made and recorded. These thermocouple readings were in millivolts and, consequently, required a conversion to degrees Fahrenheit. The temperatures indicated by the thermometers in the thermometer wells were also recorded. The rate of flow of the test liquid was determined by collecting a portion of the liquid orer a period of thirty to sixty seconds and weighing the collected material. This rate determination was made after the thermocouple and temperature readings had been recorded. After the test liquid taken from the syotem had been returned, the valves were again adjusted for another rate of flow, and equilibrium conditions were again sought.

\section{MATIRIAIS}

In this study of heat tranafer, both refrigerant and test liquids were Bocene. Since the refrigerant liquid served merely to cool the test liquid and thereby produce a transfer of heat, its properties were not examined. The properties of the test Ilquid were examined rather closely. The physical properties of the Bocene used in the 
calculation of the results are listed in Table I., page 33. The density was determined with a Testphal balance. The specific heat was determined by measuring the temperature rise of a weighed amount of Bocene when a measured quantity of electricity was introduced. Viscosities were determined at several temperatures by means of a Hoepler viscosimeter, and a smooth curre was drawn through the points to indicate the variation of the viscosity with a temperature change, Curve I., page 34. The value of the thermal conductivity that was used in the calculations was taken from the literature

(1) 


\section{TABLE I.}

PHYSICAI PROPERTIRS OF EOCENT $\left(60^{\circ} \mathrm{F}.\right)$

Density

Specific Heat

Thermal Conductivity
$50.1 \quad 2 b . / c u . f t$.

0.504 B.T.U./(2b.) $\left({ }^{0} \mathrm{~F}.\right)$

0.0875 B.T.U./ $\left(h r_{\bullet}\right)\left(s q_{0} f t_{0}\right)\left({ }^{0} F_{\cdot} / f t_{0}\right)$

DISTILLATION RANGIRS OF EOCBITE

Percent

Distilled

0

10

20

30

40

50

60

70

80

90
New

Sample

320

357

376

386

398

424

448

466

484

509
Used

Semple

332

368

384

407

424

439

455

471

490

510 


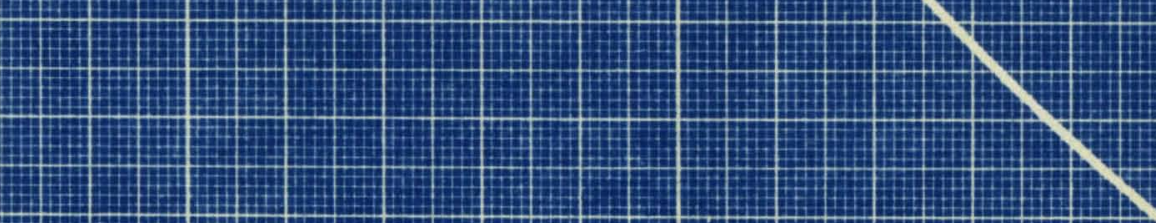

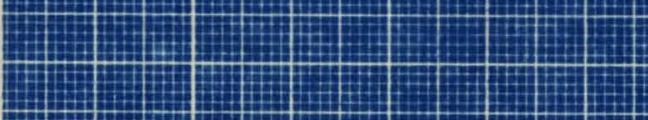

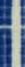
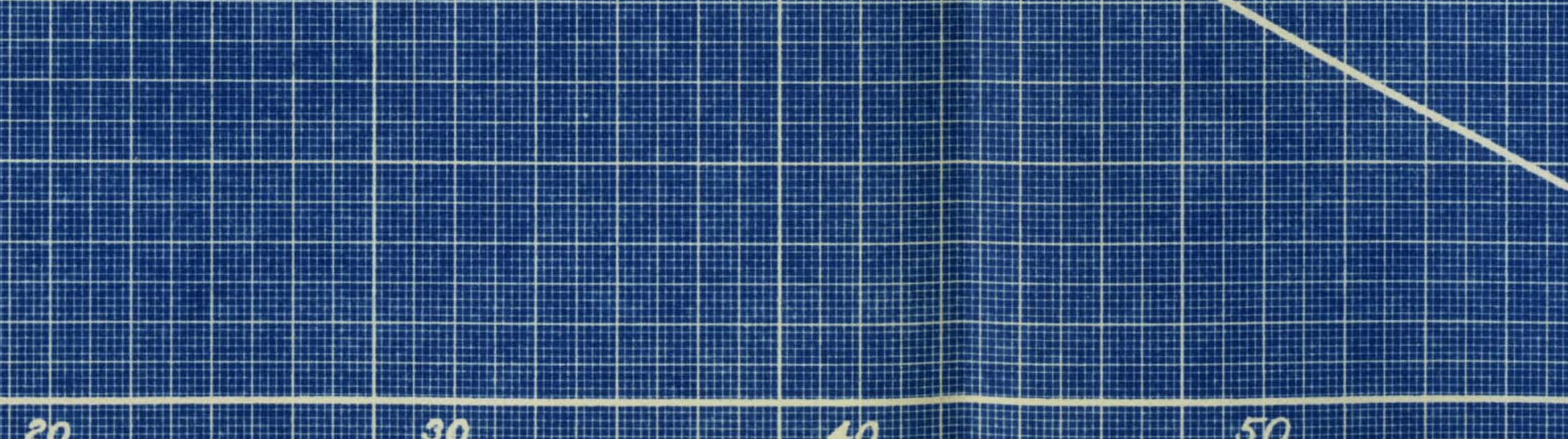
IV. DATA AND RRSULTS 
The experimental data and the calculated results are reported in the Table II, page 37 The test liquid inlet and outlet temperatures are recorded directly from the thermocouple readings. The average pipe temperature is the readings of the twelte thermocouples attached to the pipe. $\Delta t_{1}$ is the difference between the test liquid inlet temperature and the average pipe temperature. $\Delta t_{2}$ is the difference between the test liquid outlet temperature and the average pipe temperature. The logarithmic mean temperature difference is the logarithmic mean of $\Delta t_{1}$ and $\Delta t_{2}$. The test liquid $\Delta t$ is the drop in temperature in the test liquid by passage through the test section. The weight of the test liquid per minute was either determined directly or by a simple multiplication. The weight of the teat liquid per hour was obtained by multiplying the weight of the test liquid per minute by sixty. The arerage test liquid temperature is an arithmetic average of the inlet and outlet temperatures of the test liquid - the temperature at which the bulk viscosity was found. The film temperature was found by areraging the pipe temperature with the average test liquid temperature. The film 
TABIE II

HEAT TRANSFER DATA

\begin{tabular}{|c|c|c|c|c|c|c|}
\hline $\begin{array}{l}\text { Run } \\
\text { No. }\end{array}$ & $\begin{array}{l}\text { Test } \\
\text { Iiquid } \\
\text { Inlet } \\
\text { Temp. } \\
{ }_{O_{F}}\end{array}$ & $\begin{array}{l}\text { Test } \\
\text { Tiquid } \\
\text { Outlet } \\
\text { Temp. } \\
{ }^{0} \text {. }\end{array}$ & $\begin{array}{l}\text { Average } \\
\text { Pipe } \\
\text { Temp. }\end{array}$ & $\Delta t_{1}$ & $\Delta t_{2}$ & $\begin{array}{l}\text { Log } \\
\text { Mean } \\
\Delta t\end{array}$ \\
\hline $\begin{array}{l}1 \\
2 \\
3 \\
4 \\
5 \\
6 \\
7 \\
8 \\
9 \\
10 \\
11 \\
12 \\
13 \\
14 \\
15 \\
16 \\
17 \\
18 \\
19 \\
20 \\
21 \\
22 \\
23 \\
24 \\
25 \\
26 \\
27 \\
28 \\
29\end{array}$ & $\begin{array}{l}56.438 \\
57.997 \\
54.223 \\
59.300 \\
64.067 \\
54.292 \\
61.167 \\
55.400 \\
60.567 \\
59.200 \\
50.312 \\
55.607 \\
60.867 \\
57.650 \\
55.365 \\
52.215 \\
56.231 \\
56.889 \\
59.867 \\
58.031 \\
56.231 \\
55.019 \\
54.050 \\
53.774 \\
56.715 \\
54.673 \\
58.827 \\
54.085 \\
54.050 \\
54.812\end{array}$ & $\begin{array}{l}53.046 \\
55.019 \\
51.211 \\
54.154 \\
58.827 \\
50.138 \\
56.612 \\
52.285 \\
57.997 \\
56.992 \\
48.407 \\
53.011 \\
49.377 \\
54.638 \\
52.458 \\
50.588 \\
54.223 \\
54.500 \\
56.231 \\
55.607 \\
54.263 \\
53.600 \\
53.081 \\
52.665 \\
54.535 \\
52.631 \\
56.715 \\
52.250 \\
52.215 \\
52.873\end{array}$ & $\begin{array}{l}39.638 \\
39.546 \\
37.365 \\
38.865 \\
34.870 \\
29.923 \\
39.382 \\
34.008 \\
47.380 \\
47.768 \\
34.712 \\
28.573 \\
19.452 \\
25.899 \\
23.038 \\
36.877 \\
35.512 \\
38.235 \\
38.214 \\
29.343 \\
32.321 \\
35.817 \\
38.642 \\
38.145 \\
37.569 \\
37.288 \\
36.870 \\
34.781 \\
35.577 \\
34.473\end{array}$ & $\begin{array}{l}16.800 \\
18.451 \\
16.858 \\
20.435 \\
29.197 \\
24.369 \\
21.785 \\
21.392 \\
13.187 \\
11.432 \\
15.600 \\
27.034 \\
41.415 \\
31.751 \\
32.327 \\
15.338 \\
20.719 \\
18.754 \\
21.753 \\
28.688 \\
23.910 \\
19.202 \\
15.408 \\
15.629 \\
19.146 \\
17.385 \\
21.957 \\
19.304 \\
18\end{array}$ & $\begin{array}{r}13.408 \\
15.473 \\
13.846 \\
15.289 \\
23.957 \\
20.215 \\
17.230 \\
18.277 \\
10.617 \\
9.224 \\
13.695 \\
24.438 \\
29.925 \\
28.379 \\
29.420 \\
13.711 \\
18.711 \\
16.365 \\
18.117 \\
26.264 \\
22.041 \\
17.783 \\
14.439 \\
14.520 \\
16.966 \\
15.343 \\
19.845 \\
17.469 \\
16.638 \\
18.400\end{array}$ & $\begin{array}{l}15.056 \\
16.935 \\
15.318 \\
17.756 \\
26.518 \\
22.250 \\
19.438 \\
19.814 \\
11.868 \\
10.299 \\
14.642 \\
25.740 \\
35.395 \\
30.250 \\
30.882 \\
14.524 \\
19.717 \\
17.550 \\
19.899 \\
27.486 \\
22.986 \\
18.502 \\
14.933 \\
15.084 \\
18.052 \\
16.359 \\
20.905 \\
18.390 \\
17.557 \\
19.373\end{array}$ \\
\hline
\end{tabular}


HEAT TRANSFER DATA (Continued)

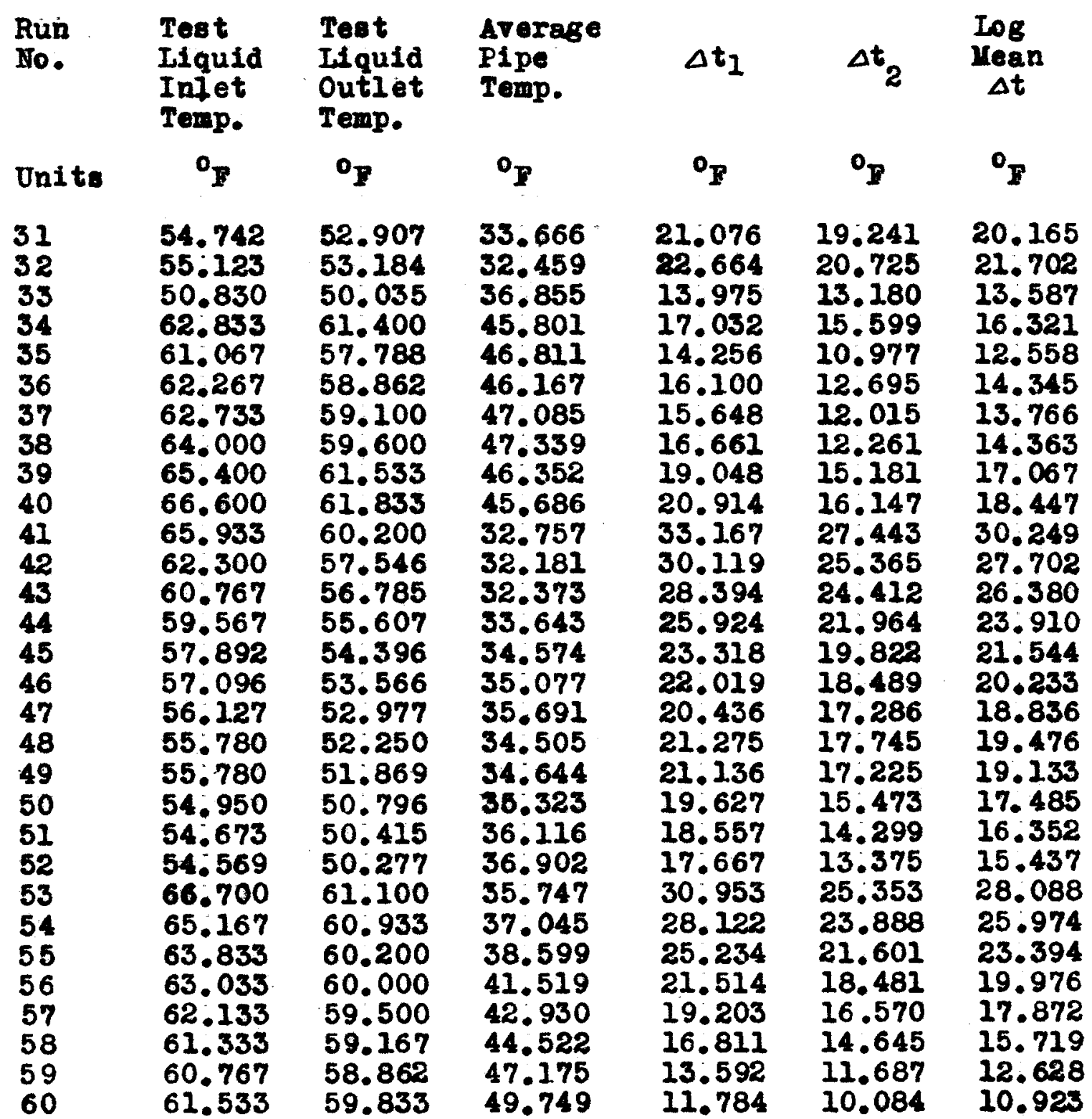


HFAT TRANSFER DATA (Continued)

\begin{tabular}{|c|c|c|c|c|c|c|}
\hline $\begin{array}{l}\text { Run } \\
\text { No. }\end{array}$ & $\begin{array}{l}\text { Test } \\
\text { Ifquid } \\
\text { Inlet } \\
\text { Temp. } \\
o_{p}\end{array}$ & $\begin{array}{l}\text { Test } \\
\text { Liquid } \\
\text { Outlet } \\
\text { Temp. } \\
{ }^{o_{5}}\end{array}$ & $\begin{array}{l}\text { Average } \\
\text { Pipe } \\
\text { Temp. }\end{array}$ & $\Delta t_{1}$ & $\Delta t_{2}$ & $\begin{array}{l}\text { Iog } \\
\text { Mean } \\
\Delta t\end{array}$ \\
\hline $\begin{array}{l}61 \\
62 \\
63 \\
64 \\
65 \\
66 \\
67 \\
68 \\
69 \\
70 \\
71 \\
72 \\
73 \\
74 \\
75 \\
76 \\
77 \\
78 \\
79 \\
80 \\
81 \\
82 \\
83 \\
84 \\
85 \\
86 \\
87 \\
88 \\
80\end{array}$ & $\begin{array}{l}53.462 \\
59.733 \\
42.593 \\
46.573 \\
49.689 \\
53.973 \\
44.011 \\
42.246 \\
42.731 \\
42.731 \\
40.066 \\
38.577 \\
32.727 \\
52.423 \\
41.623 \\
45.396 \\
38.235 \\
41.692 \\
44.046 \\
45.362 \\
42.315 \\
50.381 \\
49.239 \\
48.997 \\
43.354 \\
40.931 \\
39.388 \\
38.508 \\
48.753 \\
50.969\end{array}$ & $\begin{array}{l}50.035 \\
54.569 \\
40.896 \\
43.700 \\
47.681 \\
51.973 \\
42.280 \\
41.138 \\
41.173 \\
40.654 \\
38.093 \\
37.227 \\
31.654 \\
51.523 \\
33.004 \\
42.593 \\
46.019 \\
40.377 \\
41.900 \\
42.350 \\
40.516 \\
49.240 \\
47.167 \\
47.681 \\
40.827 \\
39.477 \\
36.915 \\
36.085 \\
45.120 \\
43.215\end{array}$ & $\begin{array}{l}42.523 \\
27.551 \\
27.327 \\
30.996 \\
34.285 \\
42.766 \\
30.511 \\
33.835 \\
32.692 \\
29.404 \\
26.981 \\
26.324 \\
20.750 \\
48.269 \\
29.459 \\
33.558 \\
38.543 \\
27.396 \\
29.785 \\
28.434 \\
26.670 \\
43.769 \\
36.223 \\
39.788 \\
26.912 \\
24.800 \\
22.342 \\
21.200 \\
36.984 \\
29.404\end{array}$ & $\begin{array}{r}10.939 \\
32.182 \\
15.266 \\
15.577 \\
15.404 \\
10.731 \\
13.500 \\
8.411 \\
10.039 \\
13.327 \\
13.085 \\
12.253 \\
11.977 \\
4.154 \\
12.164 \\
11.838 \\
9.692 \\
14.296 \\
14.261 \\
16.928 \\
15.645 \\
6.612 \\
13.016 \\
9.209 \\
16.442 \\
16.131 \\
16.996 \\
17.308 \\
11.769 \\
22.565\end{array}$ & $\begin{array}{r}7.512 \\
27.018 \\
13.569 \\
12.704 \\
13.396 \\
9.207 \\
11.769 \\
7.303 \\
8.481 \\
11.250 \\
11.112 \\
10.903 \\
10.904 \\
3.254 \\
3.545 \\
9.135 \\
7.476 \\
12.981 \\
12.115 \\
13.916 \\
13.846 \\
5.471 \\
10.944 \\
7.893 \\
13.915 \\
14.677 \\
14.573 \\
14.885 \\
8.136 \\
13.811\end{array}$ & $\begin{array}{r}9.117 \\
29.482 \\
14.399 \\
14.089 \\
14.375 \\
9.948 \\
12.613 \\
7.843 \\
9.237 \\
12.157 \\
12.069 \\
11.562 \\
11.430 \\
3.601 \\
6.989 \\
10.374 \\
8.535 \\
13.626 \\
13.156 \\
15.370 \\
14.724 \\
6.022 \\
11.948 \\
8.533 \\
15.141 \\
15.390 \\
15.751 \\
16.063 \\
9.839 \\
15.791\end{array}$ \\
\hline
\end{tabular}


HEAT TRANSFER DATA (Continued)

\begin{tabular}{|c|c|c|c|c|c|c|}
\hline $\begin{array}{l}\text { Run } \\
\text { No. }\end{array}$ & $\begin{array}{l}\text { Test } \\
\text { Iiquid } \\
\text { Inlet } \\
\text { Temp. }\end{array}$ & $\begin{array}{l}\text { Test } \\
\text { Iiquid } \\
\text { Outiet } \\
\text { Temp. }\end{array}$ & $\begin{array}{l}\text { Average } \\
\text { Pipe } \\
\text { Temp. }\end{array}$ & $\Delta t_{I}$ & $\Delta t_{2}$ & $\begin{array}{l}\text { Log } \\
\text { Mean } \\
\Delta t\end{array}$ \\
\hline Units & ${ }^{0} \mathrm{~F}$ & ${ }^{0} \mathrm{~F}$ & ${ }^{0} \mathrm{~F}$ & ${ }^{0} F$ & ${ }^{0} \mathrm{~F}$ & ${ }^{0} \mathbf{F}$ \\
\hline $\begin{array}{r}91 \\
93 \\
94 \\
95 \\
96 \\
97 \\
98 \\
99 \\
100 \\
101 \\
102 \\
103 \\
104 \\
105 \\
106 \\
108 \\
109 \\
110 \\
111 \\
112 \\
113 \\
114 \\
115 \\
116 \\
117 \\
118 \\
119 \\
120 \\
121 \\
122\end{array}$ & $\begin{array}{l}50.242 \\
38.439 \\
37.330 \\
38.715 \\
39.027 \\
44.046 \\
46.607 \\
44.981 \\
40.723 \\
41.173 \\
40.827 \\
38.300 \\
29.542 \\
38.854 \\
36.050 \\
38.404 \\
39.477 \\
37.989 \\
38.369 \\
37.642 \\
36.638 \\
36.050 \\
31.377 \\
34.212 \\
36.500 \\
37.711 \\
36.673 \\
35.739 \\
36.362 \\
36.984\end{array}$ & $\begin{array}{l}46.296 \\
35.566 \\
34.700 \\
36.535 \\
37.192 \\
38.162 \\
43.354 \\
40.100 \\
37.296 \\
38.335 \\
38.231 \\
36.984 \\
28.712 \\
33.835 \\
33.869 \\
36.466 \\
37.158 \\
36.223 \\
35.600 \\
34.769 \\
33.558 \\
32.900 \\
29.715 \\
32.000 \\
34.215 \\
34.077 \\
33.176 \\
32.450 \\
32.934 \\
33.385\end{array}$ & $\begin{array}{l}38.023 \\
24.247 \\
25.250 \\
26.600 \\
27.846 \\
22.965 \\
23.277 \\
28.088 \\
26.358 \\
26.358 \\
18.292 \\
15.765 \\
18.880 \\
17.046 \\
20.300 \\
26.635 \\
25.942 \\
25.631 \\
24.765 \\
21.927 \\
20.646 \\
19.434 \\
19.538 \\
21.200 \\
22.792 \\
21.442 \\
20.715 \\
20.300 \\
19.781 \\
20.335\end{array}$ & $\begin{array}{l}12.219 \\
14.192 \\
12.080 \\
12.115 \\
11.181 \\
22.081 \\
23.330 \\
15.993 \\
14.365 \\
14.815 \\
22.535 \\
22.535 \\
10.662 \\
21.808 \\
15.750 \\
11.769 \\
13.535 \\
12.358 \\
13.604 \\
15.715 \\
15.992 \\
16.616 \\
11.839 \\
12.912 \\
13.708 \\
16.269 \\
15.958 \\
15.439 \\
16.581 \\
16.649\end{array}$ & $\begin{array}{r}8.273 \\
11.319 \\
9.450 \\
9.935 \\
9.346 \\
15.197 \\
20.077 \\
12.012 \\
10.938 \\
11.977 \\
19.939 \\
21.219 \\
9.832 \\
16.789 \\
13.569 \\
9.831 \\
11.216 \\
10.592 \\
10.835 \\
12.842 \\
12.912 \\
13.466 \\
10.177 \\
10.800 \\
11.423 \\
12.635 \\
12.461 \\
12.150 \\
13.153 \\
13.050\end{array}$ & $\begin{array}{l}10.011 \\
12.699 \\
10.709 \\
10.987 \\
10.234 \\
15.752 \\
21.659 \\
13.905 \\
12.571 \\
13.343 \\
21.207 \\
20.274 \\
10.239 \\
19.186 \\
14.632 \\
10.769 \\
12.338 \\
111450 \\
12.168 \\
14.228 \\
14.395 \\
14.983 \\
10.986 \\
11.823 \\
12.528 \\
14.372 \\
14.134 \\
13.727 \\
14.798 \\
14.774\end{array}$ \\
\hline
\end{tabular}


HEAT TRANSTER DATA (Continued)

\begin{tabular}{|c|c|c|c|c|c|c|}
\hline $\begin{array}{l}\text { Run } \\
\text { No. }\end{array}$ & $\begin{array}{l}\text { Test } \\
\text { Liquid } \\
\text { Inlet } \\
\text { Temp. }\end{array}$ & $\begin{array}{l}\text { Test } \\
\text { Iiquid } \\
\text { Outiet } \\
\text { Temp. }\end{array}$ & $\begin{array}{l}\text { Average } \\
\text { PI pe } \\
\text { Temp. }\end{array}$ & $\Delta t_{I}$ & $\Delta t_{2}$ & $\begin{array}{l}\text { Log } \\
\text { Yean } \\
\Delta t\end{array}$ \\
\hline Units & ${ }^{0} \mathrm{P}$ & ${ }^{0} \mathrm{P}$ & $\mathrm{O}_{\mathrm{F}}$ & ${ }^{O F}$ & $o_{F}$ & ${ }^{0} \mathrm{~F}$ \\
\hline $\begin{array}{l}129 \\
130 \\
131 \\
132 \\
133 \\
134 \\
135 \\
136 \\
137 \\
138 \\
139 \\
140 \\
141 \\
142 \\
143 \\
144 \\
145 \\
146 \\
147 \\
148 \\
149 \\
150 \\
151 \\
152 \\
153 \\
154 \\
155\end{array}$ & $\begin{array}{l}20.854 \\
33.038 \\
32.1 .04 \\
32.865 \\
32.865 \\
33.489 \\
32.104 \\
31.862 \\
32.000 \\
32.069 \\
32.000 \\
32.000 \\
32.727 \\
32.242 \\
34.215 \\
34.215 \\
36.327 \\
32.000 \\
32.761 \\
31.688 \\
32.277 \\
32.208 \\
35.219 \\
37.123 \\
36.604 \\
35.323 \\
34.077 \\
34.458\end{array}$ & $\begin{array}{l}20.231 \\
28.400 \\
28.643 \\
29.508 \\
29.715 \\
29.231 \\
29.785 \\
28.989 \\
28.989 \\
28.608 \\
28.712 \\
28.330 \\
28.196 \\
29.093 \\
29.750 \\
29.992 \\
26.566 \\
29.923 \\
30.477 \\
28.643 \\
28.781 \\
28.192 \\
25.492 \\
26.239 \\
25.596 \\
27.396 \\
28.643 \\
28.123\end{array}$ & $\begin{array}{l}16.561 \\
17.220 \\
16.942 \\
17.393 \\
16.042 \\
15.800 \\
15.627 \\
14.554 \\
13.100 \\
12.789 \\
13.031 \\
12.407 \\
11.957 \\
12.580 \\
13.550 \\
13.100 \\
12.442 \\
12.546 \\
11.854 \\
15.038 \\
12.580 \\
11.508 \\
12.869 \\
12.615 \\
13.100 \\
12.927 \\
12.442 \\
11.473\end{array}$ & $\begin{array}{l}4.293 \\
15.818 \\
15.162 \\
15.472 \\
16.823 \\
17.689 \\
16.477 \\
17.308 \\
18.900 \\
19.380 \\
18.969 \\
19.593 \\
20.770 \\
19.662 \\
20.665 \\
21.115 \\
23.885 \\
19.454 \\
20.907 \\
16.650 \\
19.697 \\
20.700 \\
22.950 \\
24.508 \\
23.504 \\
22.396 \\
21.635 \\
22.985\end{array}$ & $\begin{array}{l}3.670 \\
11.180 \\
11.701 \\
12.115 \\
13.673 \\
13.431 \\
14.158 \\
14.435 \\
15.889 \\
15.819 \\
15.681 \\
15.923 \\
16.235 \\
16.513 \\
16.200 \\
16.892 \\
14.124 \\
17.469 \\
18.623 \\
13.605 \\
16.201 \\
16.684 \\
13.223 \\
13.624 \\
12.694 \\
14.469 \\
16.201 \\
16.650\end{array}$ & $\begin{array}{r}3.973 \\
13.362 \\
13.666 \\
13.725 \\
15.674 \\
15.459 \\
15.285 \\
15.825 \\
17.348 \\
17.489 \\
17.270 \\
17.691 \\
18.407 \\
17.068 \\
18.339 \\
18.922 \\
18.576 \\
19.295 \\
19.740 \\
15.074 \\
17.482 \\
18.617 \\
17.639 \\
18.070 \\
17.421 \\
18.142 \\
18.783 \\
18.335\end{array}$ \\
\hline
\end{tabular}


HAAT TRANBPER DATA (Continued)

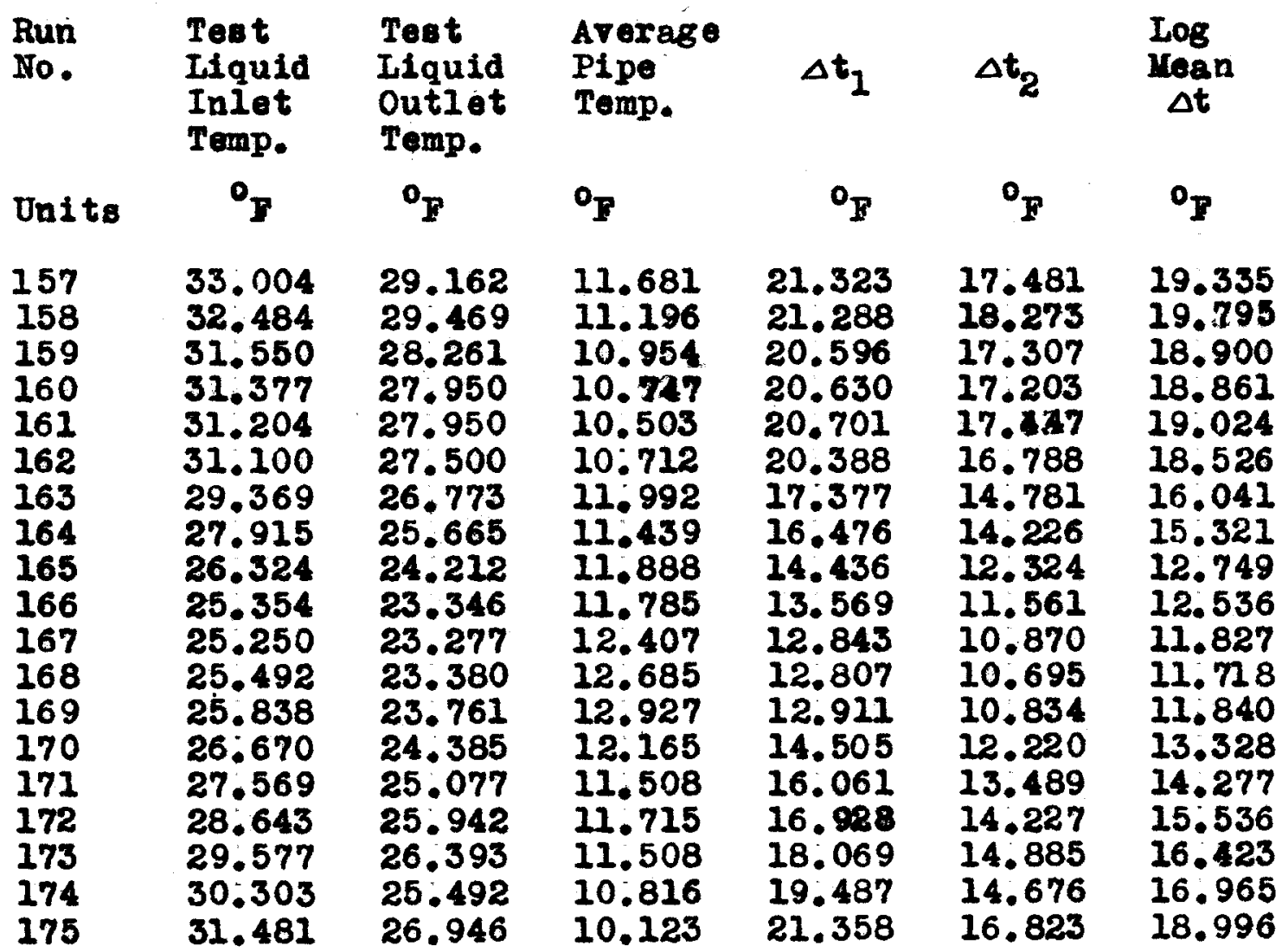


HEAT TRATSFER DATA (Continued)

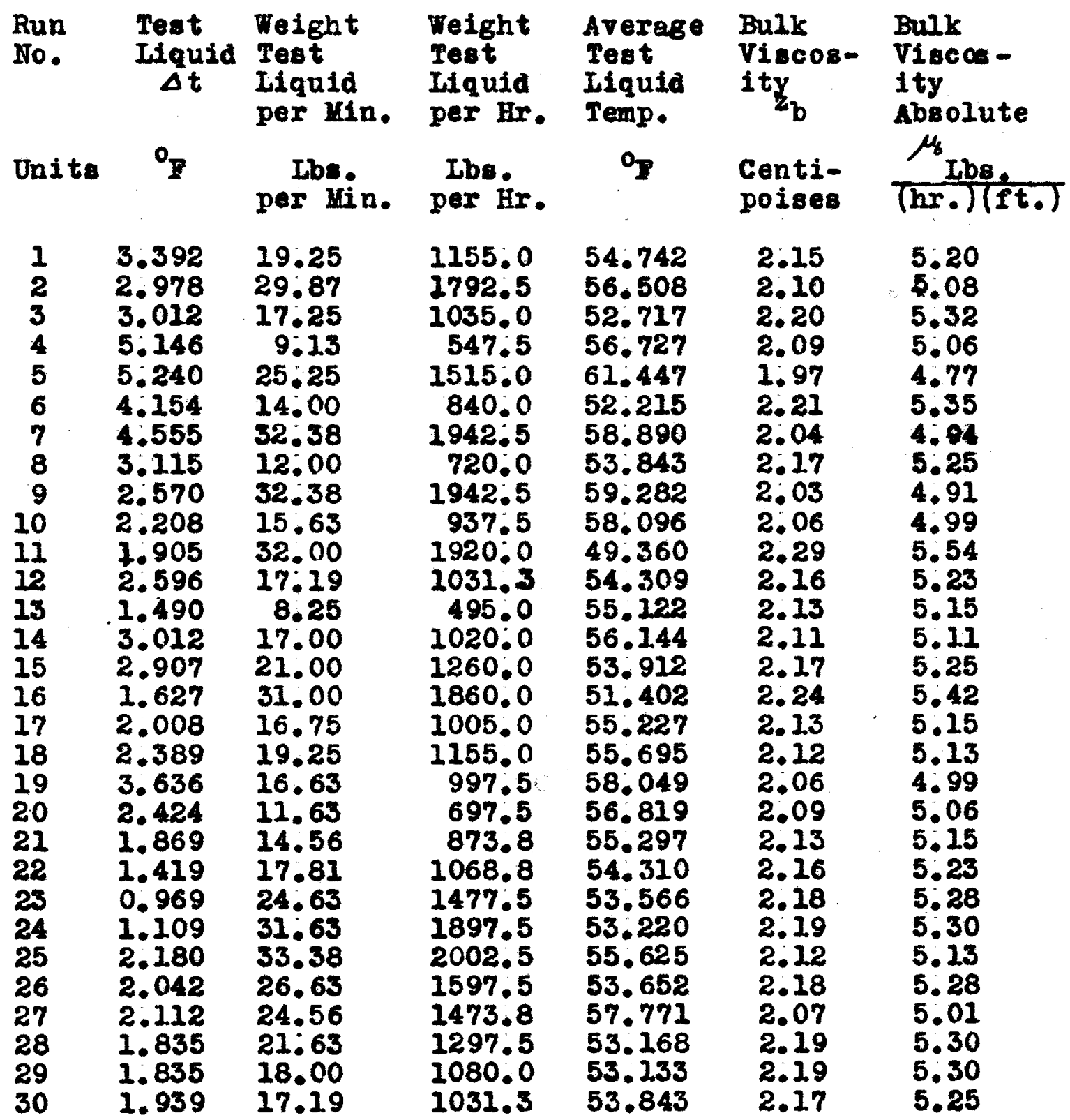


HEAT TRAUSFER DATA (Continued)

\begin{tabular}{|c|c|c|c|c|c|c|}
\hline $\begin{array}{l}\text { Run } \\
\text { No. }\end{array}$ & $\begin{array}{l}\text { Test } \\
\text { Liquid } \\
\Delta t\end{array}$ & $\begin{array}{l}\text { Welght } \\
\text { Test } \\
\text { Ilquid } \\
\text { Per yin. }\end{array}$ & $\begin{array}{l}\text { Weight } \\
\text { Test } \\
\text { Liquid } \\
\text { per Hr. }\end{array}$ & $\begin{array}{l}\text { Average } \\
\text { Test } \\
\text { Liquid } \\
\text { Temp. }\end{array}$ & $\begin{array}{l}\text { Bulk } \\
\text { Viscos- } \\
\text { ity } \\
z_{b}\end{array}$ & $\begin{array}{l}\text { Bulk } \\
\text { Viscos- } \\
\text { ity } \\
\text { Absolute }\end{array}$ \\
\hline Units & ${ }^{0} 5$ & $\begin{array}{l}\text { Ibs. } \\
\text { per Min. }\end{array}$ & $\begin{array}{l}\text { Lbs. } \\
\text { per Hr. }\end{array}$ & ${ }^{\circ} \mathrm{F}$ & $\begin{array}{l}\text { Conti- } \\
\text { poises }\end{array}$ & $\frac{\mu_{b}}{\text { Ibs. }}$ \\
\hline $\begin{array}{l}31 \\
32 \\
33 \\
34 \\
35 \\
36 \\
37 \\
38 \\
39 \\
40 \\
41 \\
42 \\
43 \\
44 \\
45 \\
46 \\
47 \\
48 \\
49 \\
50 \\
51 \\
52 \\
53 \\
54 \\
55 \\
56 \\
57 \\
58 \\
59\end{array}$ & $\begin{array}{l}1.835 \\
1.939 \\
0.795 \\
1.433 \\
3.279 \\
3.405 \\
3.633 \\
4.400 \\
3.867 \\
4.767 \\
5.733 \\
4.754 \\
3.982 \\
3.960 \\
3.496 \\
3.530 \\
3.150 \\
3.530 \\
3.911 \\
4.154 \\
4.258 \\
4.292 \\
5.600 \\
4.234 \\
3.633 \\
3.033 \\
2.633 \\
2.166 \\
1.905 \\
1.700\end{array}$ & $\begin{array}{r}15.50 \\
14.00 \\
33.00 \\
33.00 \\
31.88 \\
24.88 \\
24.00 \\
18.38 \\
14.50 \\
12.38 \\
8.88 \\
11.00 \\
12.88 \\
15.50 \\
17.00 \\
18.38 \\
20.50 \\
23.13 \\
26.13 \\
27.25 \\
31.88 \\
32.00 \\
8.00 \\
9.50 \\
13.25 \\
15.75 \\
19.13 \\
22.25 \\
29.25 \\
32.13\end{array}$ & $\begin{array}{r}930.0 \\
840.0 \\
1980.0 \\
1980.0 \\
1912.5 \\
1492.5 \\
1440.0 \\
1102.5 \\
870.0 \\
742.5 \\
532.5 \\
660.0 \\
772.5 \\
930.0 \\
1020.0 \\
1102.5 \\
1230.0 \\
1387.5 \\
1567.5 \\
1635.0 \\
1912.5 \\
1920.0 \\
480.0 \\
570.0 \\
795.0 \\
945.0 \\
1147.5 \\
1335.0 \\
1755.0 \\
1927.5\end{array}$ & $\begin{array}{l}53.825 \\
54.154 \\
50.433 \\
62.117 \\
59.428 \\
60.565 \\
60.917 \\
61.800 \\
63.467 \\
64.217 \\
63.067 \\
59.923 \\
58.776 \\
57.587 \\
56.144 \\
55.331 \\
54.552 \\
54.015 \\
53.825 \\
52.873 \\
52.544 \\
52.423 \\
63.900 \\
63.050 \\
62.017 \\
61.517 \\
60.816 \\
60.260 \\
59.815 \\
60.683\end{array}$ & $\begin{array}{l}2.17 \\
2.16 \\
2.27 \\
1.96 \\
2.06 \\
2.00 \\
1.99 \\
1.97 \\
1.93 \\
1.91 \\
1.94 \\
2.01 \\
2.04 \\
2.07 \\
2.11 \\
2.13 \\
2.15 \\
2.16 \\
2.17 \\
2.19 \\
2.20 \\
2.21 \\
1.92 \\
1.94 \\
1.96 \\
1.98 \\
1.99 \\
2.01 \\
2.02 \\
1.99\end{array}$ & $\begin{array}{l}5.25 \\
5.23 \\
5.49 \\
4.74 \\
4.99 \\
4.84 \\
4.82 \\
4.77 \\
4.67 \\
4.62 \\
4.69 \\
4.86 \\
4.94 \\
5.01 \\
5.11 \\
5.15 \\
5.20 \\
5.23 \\
5.25 \\
5.30 \\
5.32 \\
5.35 \\
4.65 \\
4.69 \\
4.74 \\
4.79 \\
4.82 \\
4.86 \\
4.89 \\
4.82\end{array}$ \\
\hline
\end{tabular}


HEAT TRANBSER DATA (Continued)

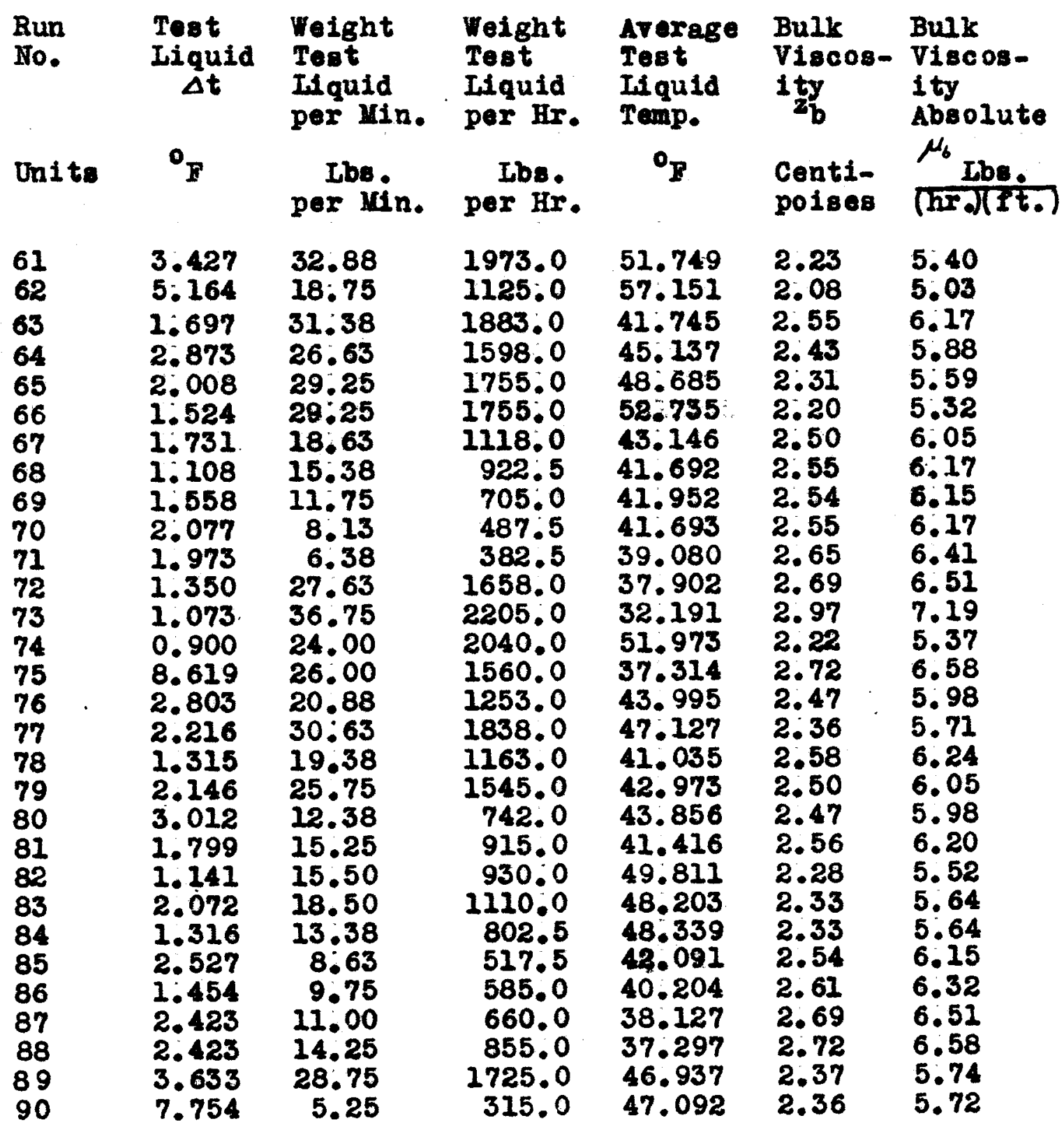


HEAT TRANGFER DATA (Continued)

\begin{tabular}{|c|c|c|c|c|c|c|}
\hline $\begin{array}{l}\text { Run } \\
\text { No. }\end{array}$ & $\begin{array}{l}\text { Test } \\
\text { Iqquid } \\
\Delta t\end{array}$ & $\begin{array}{l}\text { Teight } \\
\text { Test } \\
\text { Iiquid } \\
\text { per Yin. }\end{array}$ & $\begin{array}{l}\text { Weight } \\
\text { Test } \\
\text { Liquid } \\
\text { per Hr. }\end{array}$ & $\begin{array}{l}\text { Average } \\
\text { Test } \\
\text { Iiquid } \\
\text { Temp. }\end{array}$ & $\begin{array}{l}\text { Bulk } \\
\text { Viscos- } \\
\text { ity } \\
z_{b}\end{array}$ & $\begin{array}{l}\text { Bulk } \\
\text { Viscos- } \\
\text { ity } \\
\text { Absolute } \\
\mu_{b}\end{array}$ \\
\hline Units & ${ }^{0} \mathrm{z}$ & $\begin{array}{l}\text { Lbs. } \\
\text { por Min. }\end{array}$ & $\begin{array}{l}\text { Lbs. } \\
\text { per Hr. }\end{array}$ & ${ }^{O_{F}}$ & $\begin{array}{l}\text { Cent1- } \\
\text { poises }\end{array}$ & $\frac{\mathrm{Lbg}_{\mathrm{f}}}{(\mathrm{hr} \cdot)\left(\mathrm{ft}_{+}\right)}$ \\
\hline $\begin{array}{l}91 \\
93 \\
94 \\
95 \\
96 \\
97 \\
98 \\
99 \\
100 \\
101 \\
102 \\
103 \\
104 \\
105 \\
106 \\
108 \\
109 \\
110 \\
111 \\
112 \\
113 \\
114 \\
115 \\
116 \\
117 \\
118 \\
119 \\
120 \\
121 \\
122\end{array}$ & $\begin{array}{l}3.946 \\
2.873 \\
2.630 \\
2.380 \\
1.835 \\
5.884 \\
3.253 \\
3.981 \\
3.427 \\
2.838 \\
2.596 \\
1.316 \\
0.830 \\
5.019 \\
2.181 \\
1.938 \\
2.319 \\
1.766 \\
2.769 \\
2.873 \\
3.080 \\
3.150 \\
1.662 \\
2.112 \\
2.285 \\
3.634 \\
3.497 \\
3.289 \\
3.428 \\
3.599\end{array}$ & $\begin{array}{r}8.13 \\
9.75 \\
9.75 \\
14.25 \\
13.00 \\
6.00 \\
6.00 \\
9.13 \\
12.75 \\
19.75 \\
17.35 \\
16.25 \\
28.00 \\
28.25 \\
30.75 \\
17.88 \\
14.25 \\
11.63 \\
9.50 \\
8.88 \\
7.75 \\
7.13 \\
27.50 \\
26.50 \\
21.38 \\
15.25 \\
12.63 \\
10.63 \\
8.75 \\
6.63\end{array}$ & $\begin{array}{r}487.5 \\
585.0 \\
585.0 \\
855.0 \\
780.0 \\
360.0 \\
360.0 \\
547.5 \\
765.0 \\
1186.0 \\
1028.0 \\
975.0 \\
1680.0 \\
1695.0 \\
1845.0 \\
1073.0 \\
855.0 \\
697.5 \\
570.0 \\
532.5 \\
465.0 \\
427.5 \\
1650.0 \\
1590.0 \\
1283.0 \\
915.0 \\
757.5 \\
637.5 \\
525.0 \\
397.5\end{array}$ & $\begin{array}{l}48.269 \\
37.003 \\
36.015 \\
37.625 \\
38.110 \\
41.104 \\
44.981 \\
42.091 \\
39.010 \\
39.754 \\
39.529 \\
37.642 \\
29.127 \\
36.345 \\
34.960 \\
37.435 \\
38.318 \\
37.106 \\
36.985 \\
36.206 \\
35.098 \\
24.475 \\
30.546 \\
33.056 \\
35.358 \\
35.894 \\
34.925 \\
34.095 \\
34.648 \\
35.185\end{array}$ & $\begin{array}{l}2.33 \\
2.74 \\
2.78 \\
2.71 \\
2.69 \\
2.57 \\
2.43 \\
2.54 \\
2.65 \\
2.62 \\
2.63 \\
2.71 \\
3.15 \\
2.77 \\
2.82 \\
2.72 \\
2.68 \\
2.73 \\
2.73 \\
2.97 \\
2.82 \\
2.85 \\
3.06 \\
2.92 \\
2.80 \\
2.78 \\
2.84 \\
2.87 \\
2.84 \\
2.82\end{array}$ & $\begin{array}{l}5.64 \\
6.63 \\
6.73 \\
6.56 \\
6.51 \\
6.22 \\
5.88 \\
6.1 .5 \\
6.41 \\
6.34 \\
6.36 \\
6.56 \\
7.62 \\
6.70 \\
6.82 \\
6.58 \\
6.49 \\
6.61 \\
6.61 \\
7.19 \\
6.82 \\
6.90 \\
7.41 \\
7.07 \\
6.78 \\
6.73 \\
6.85 \\
6.95 \\
6.87 \\
6.82\end{array}$ \\
\hline
\end{tabular}


HEAT TRANGFER DATA (Continued)

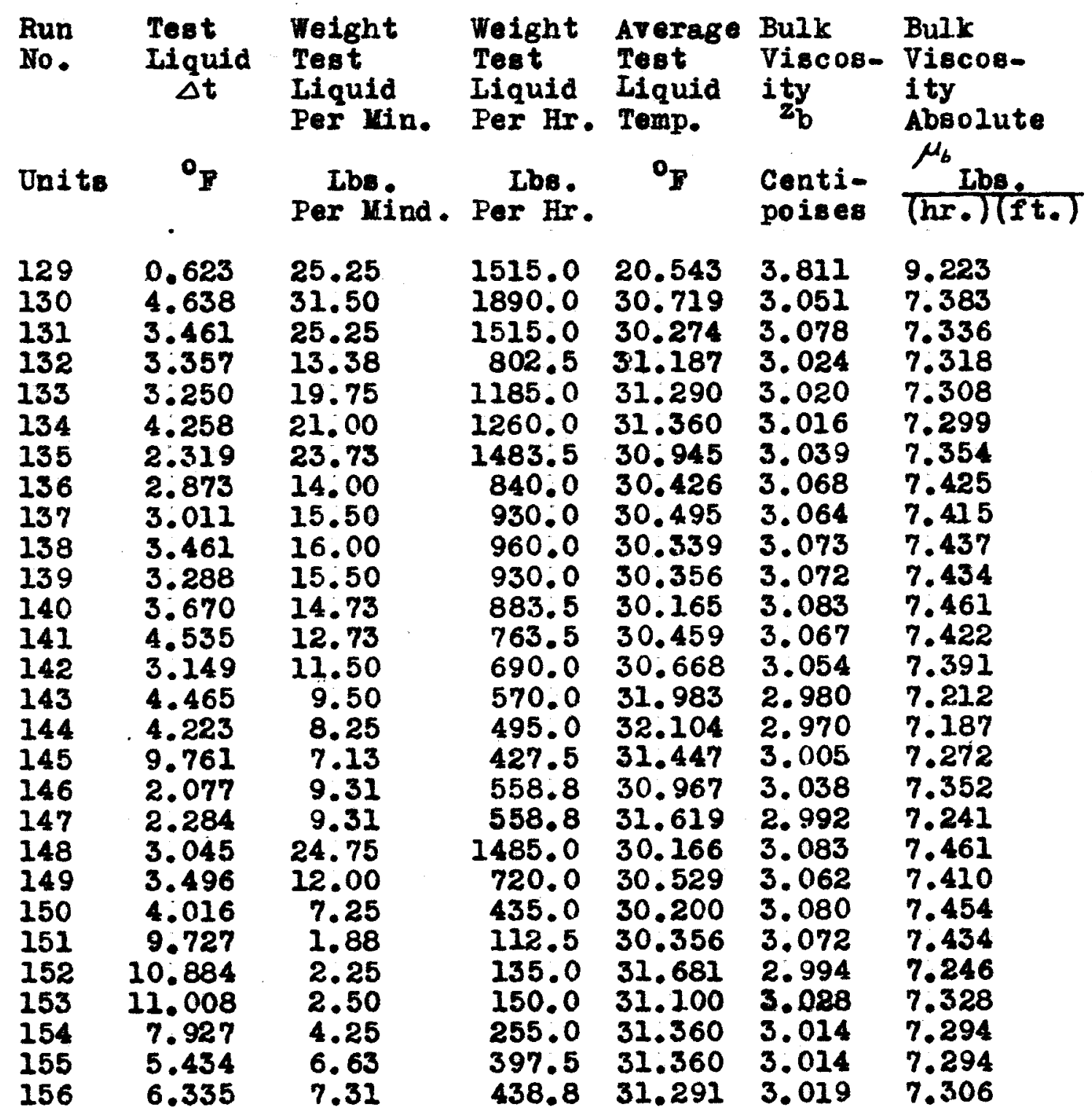


HBAT TRA RSFTR DATA (Continued)

\begin{tabular}{|c|c|c|c|c|c|c|}
\hline $\begin{array}{l}\text { Run } \\
\text { No. }\end{array}$ & $\begin{array}{l}\text { Test } \\
\text { Ifquid } \\
\Delta t\end{array}$ & $\begin{array}{l}\text { Weight } \\
\text { Tost } \\
\text { Iiquid } \\
\text { per rin. }\end{array}$ & $\begin{array}{l}\text { Weight } \\
\text { Test } \\
\text { Liquid } \\
\text { per Hr. }\end{array}$ & $\begin{array}{l}\text { Average } \\
\text { Test } \\
\text { Liquid } \\
\text { Temp. }\end{array}$ & $\begin{array}{l}\text { Bulk } \\
\text { Viscos- } \\
\text { ity } \\
\text { b }\end{array}$ & $\begin{array}{l}\text { Bulk } \\
\text { Viscos- } \\
\text { ity } \\
\text { Absolute }\end{array}$ \\
\hline Units & ${ }^{0} p$ & $\begin{array}{l}\text { Ibs. } \\
\text { per Kin. }\end{array}$ & $\begin{array}{l}\text { Lbs. } \\
\text { per Hr. }\end{array}$ & ${ }^{0} \mathbf{P}$ & $\begin{array}{l}\text { Centi- } \\
\text { poises }\end{array}$ & $\frac{\text { Lbs. }}{\left(h x_{0}\right)\left(f t_{0}\right)}$ \\
\hline $\begin{array}{l}157 \\
158 \\
159 \\
160 \\
161 \\
162 \\
163 \\
164 \\
165 \\
166 \\
167 \\
168 \\
169 \\
170 \\
171 \\
172 \\
173 \\
174 \\
175\end{array}$ & $\begin{array}{l}3.842 \\
3.015 \\
3.289 \\
3.427 \\
3.254 \\
3.600 \\
2.596 \\
2.250 \\
2.112 \\
2.008 \\
1.973 \\
2.1 .12 \\
2.077 \\
2.285 \\
2.492 \\
2.701 \\
3.284 \\
4.811 \\
4.535\end{array}$ & $\begin{array}{r}9.13 \\
8.63 \\
10.75 \\
11.75 \\
11.63 \\
16.00 \\
23.75 \\
32.00 \\
36.00 \\
36.00 \\
35.00 \\
28.25 \\
26.00 \\
18.75 \\
13.75 \\
10.25 \\
9.00 \\
7.25 \\
3.00\end{array}$ & $\begin{array}{r}547.5 \\
517.5 \\
645.0 \\
705.0 \\
697.5 \\
960.0 \\
1425.0 \\
1920.0 \\
2160.0 \\
2160.0 \\
2100.0 \\
1695.0 \\
1560.0 \\
1125.0 \\
825.0 \\
615.0 \\
540.0 \\
435.0 \\
180.0\end{array}$ & $\begin{array}{l}31.083 \\
30.977 \\
29.906 \\
29.664 \\
29.577 \\
29.300 \\
28.071 \\
26.790 \\
25.268 \\
24.350 \\
24.864 \\
24.436 \\
24.800 \\
25.528 \\
26.323 \\
27.293 \\
27.985 \\
27.898 \\
29.214\end{array}$ & $\begin{array}{l}3.028 \\
3.040 \\
3.100 \\
3.213 \\
3.120 \\
3.135 \\
3.210 \\
3.300 \\
3.412 \\
3.483 \\
3.490 \\
3.475 \\
3.448 \\
3.400 \\
3.337 \\
3.266 \\
3.220 \\
3.223 \\
3.139\end{array}$ & $\begin{array}{l}7.328 \\
7.357 \\
7.502 \\
7.534 \\
7.550 \\
7.587 \\
7.768 \\
7.986 \\
8.257 \\
8.429 \\
8.446 \\
8.410 \\
8.344 \\
8.228 \\
8.076 \\
7.904 \\
7.792 \\
7.800 \\
7.596\end{array}$ \\
\hline
\end{tabular}


HEAT TRANSFTR DATA (Continued)

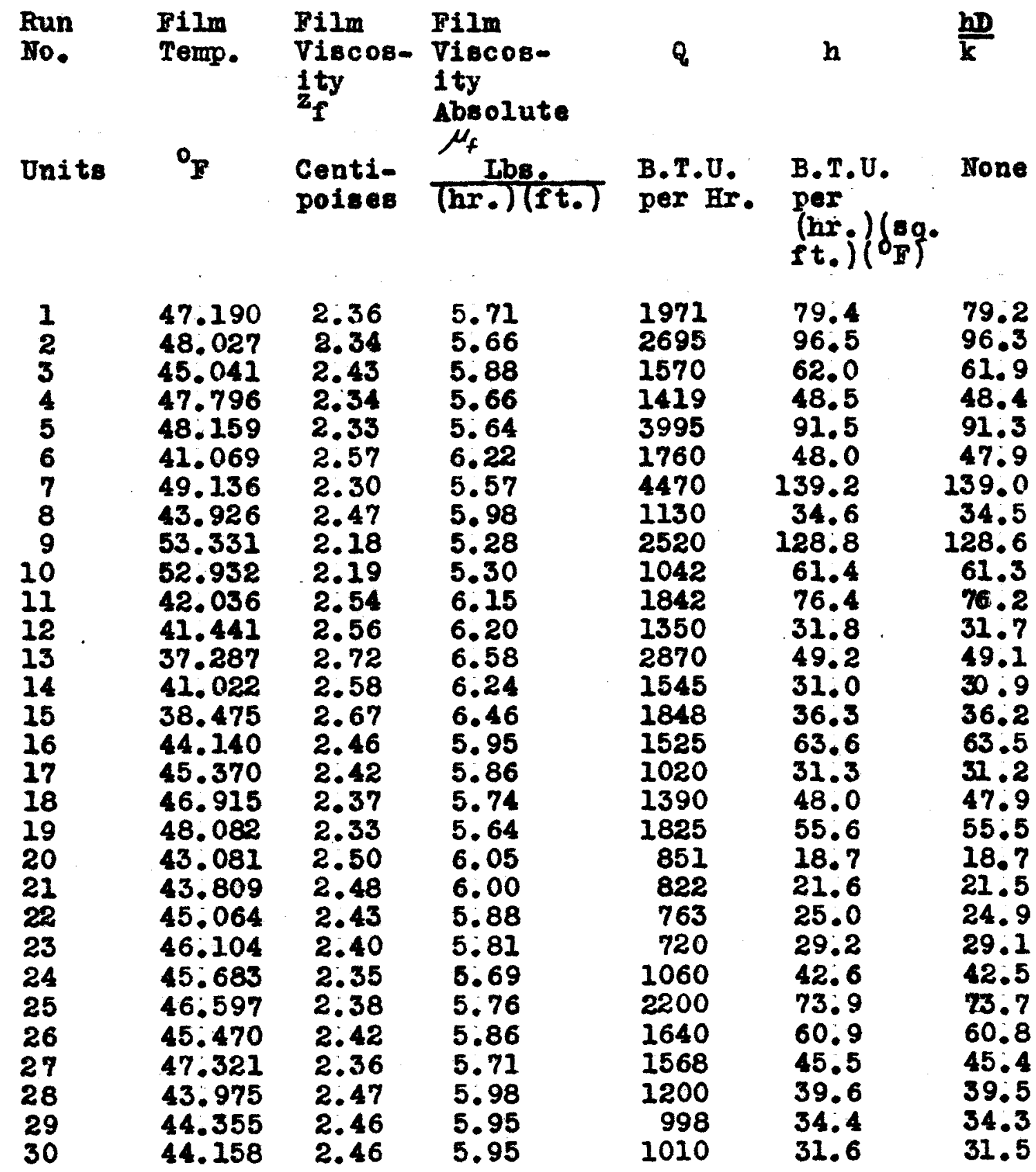


HEAT TRANSTER DATA (Continued)

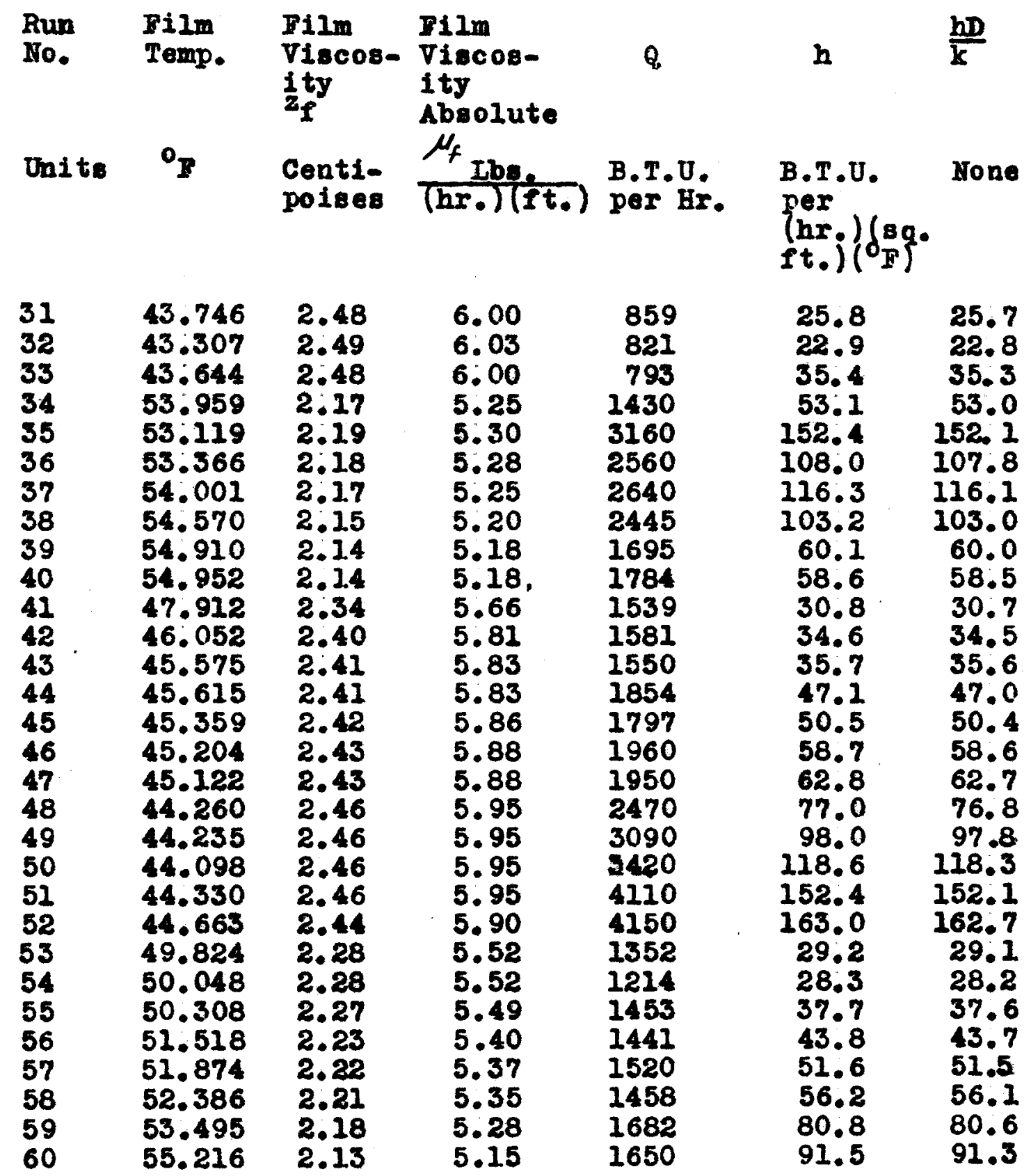


HEAT TRANSFIRR DATA (Continued)

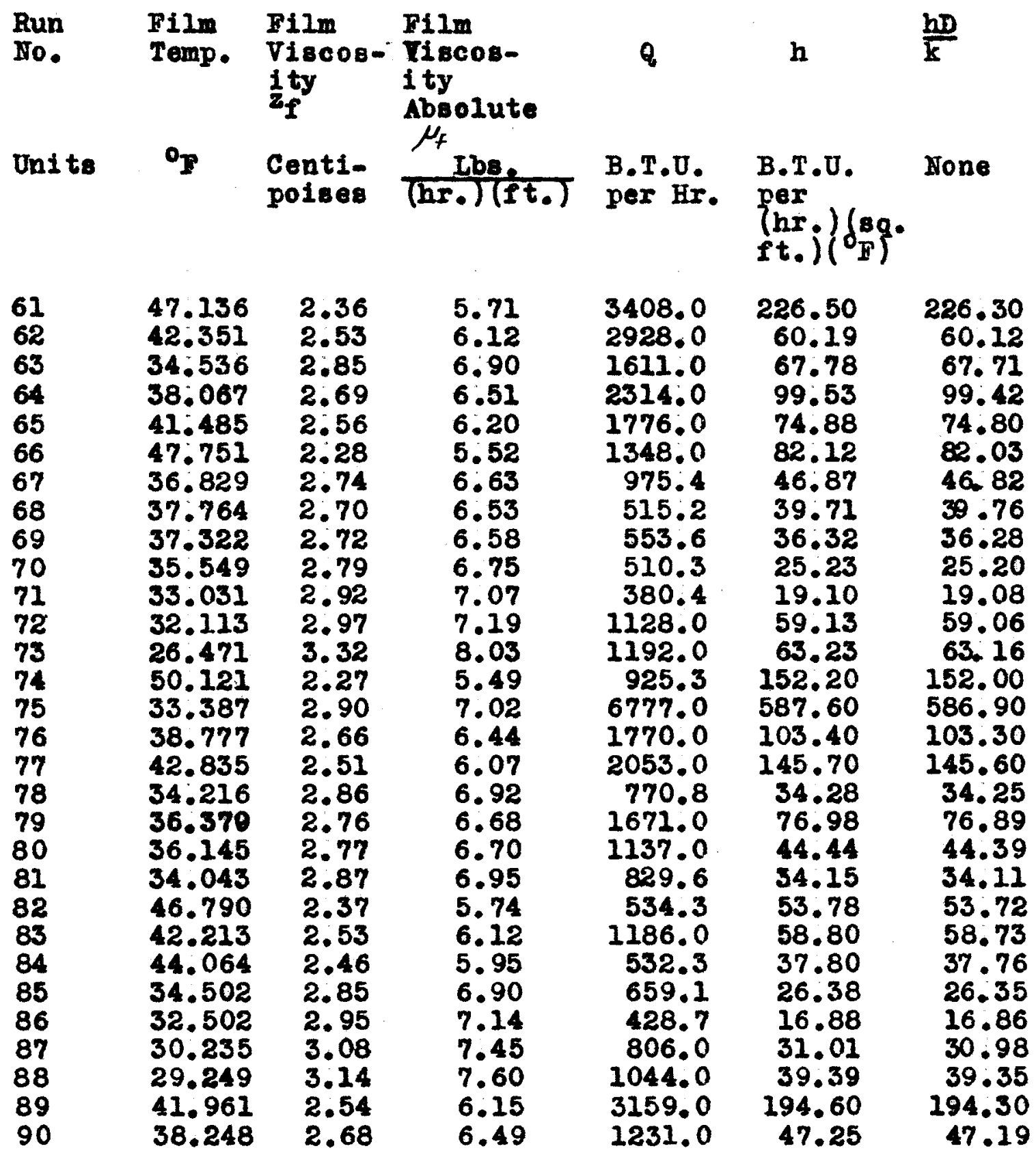


HIAT TRANSFrR DATa (Continued)

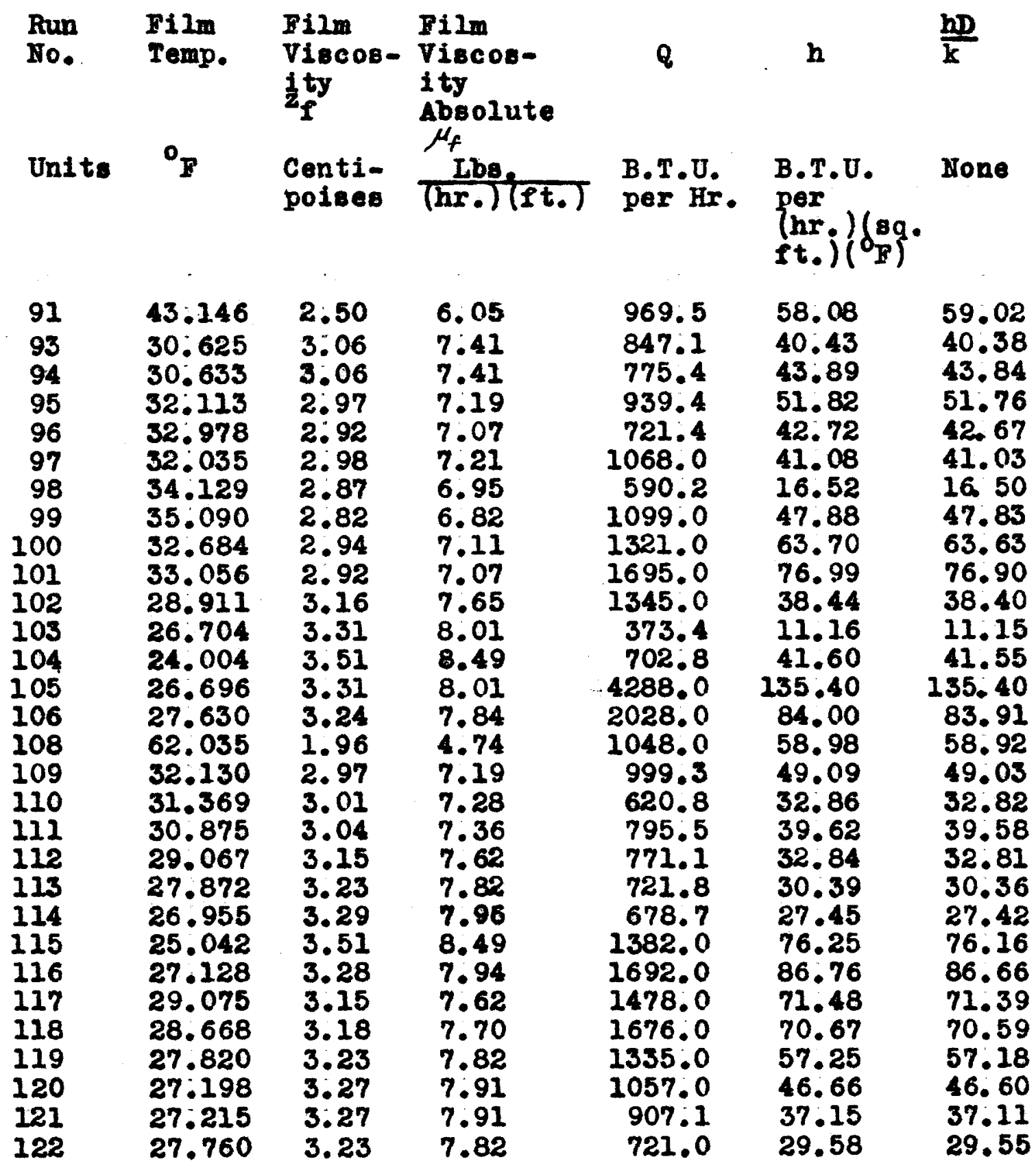


HEAT TRANSFER DATA (Continued)

\begin{tabular}{|c|c|c|c|c|c|c|}
\hline $\begin{array}{l}\text { Run } \\
\text { No. }\end{array}$ & $\begin{array}{l}\text { Film } \\
\text { Temp. }\end{array}$ & $\begin{array}{l}\text { Film } \\
\text { Viscos- } \\
\text { ity } \\
z_{f}\end{array}$ & $\begin{array}{l}\text { Film } \\
\text { Viscos- } \\
\text { Ity } \\
\text { Absolute } \\
\mu_{f}\end{array}$ & 8 & $\mathbf{h}$ & $\frac{h D}{k}$ \\
\hline Units & ${ }^{O_{F}}$ & $\begin{array}{l}\text { Cent1- } \\
\text { poises }\end{array}$ & $\frac{\text { Lbs. }}{(\mathrm{hr}) / \mathrm{ft}}$ & $\begin{array}{l}\text { B.T.U. } \\
\text { per Hr. }\end{array}$ & $\begin{array}{l}\text { B.T.U. } \\
\text { per } \\
(\mathrm{hr} .)\left(\delta_{\mathrm{f}}\right. \\
\text { ft. }\end{array}$ & None \\
\hline $\begin{array}{l}129 \\
130 \\
131 \\
132 \\
133 \\
134 \\
135 \\
136 \\
137 \\
138 \\
139 \\
140 \\
141 \\
142 \\
143 \\
144 \\
145 \\
146 \\
147 \\
148 \\
149 \\
150 \\
151 \\
152 \\
153 \\
154 \\
155 \\
156\end{array}$ & $\begin{array}{l}18.552 \\
23.970 \\
23.608 \\
24.290 \\
23: 666 \\
23.580 \\
23.286 \\
22.490 \\
21.798 \\
21.564 \\
21.694 \\
21.296 \\
21.208 \\
21.624 \\
22.767 \\
22.602 \\
22.445 \\
21.757 \\
21.737 \\
22.602 \\
21.555 \\
20.854 \\
21.313 \\
22.148 \\
22.100 \\
22.144 \\
21.901 \\
21.382\end{array}$ & $\begin{array}{l}4.00 \\
3.52 \\
3.54 \\
3.49 \\
3.54 \\
3.55 \\
3.57 \\
3.64 \\
3.70 \\
3.72 \\
3.71 \\
3.74 \\
3.75 \\
3.71 \\
3.62 \\
3.63 \\
3.64 \\
3.71 \\
3.71 \\
3.63 \\
3.72 \\
3.78 \\
3.74 \\
3.67 \\
3.68 \\
3.67 \\
3.69 \\
3.74\end{array}$ & $\begin{array}{l}9.67 \\
8.51 \\
8.57 \\
8.44 \\
8.57 \\
8.59 \\
8.64 \\
8.81 \\
8.95 \\
9.01 \\
8.98 \\
9.06 \\
9.07 \\
8.99 \\
8.76 \\
8.78 \\
8.81 \\
8.98 \\
8.97 \\
8.78 \\
9.01 \\
9.15 \\
9.05 \\
8.88 \\
8.89 \\
8.88 \\
8.93 \\
9.05\end{array}$ & $\begin{array}{r}475.7 \\
4418.0 \\
2642.7 \\
1357.8 \\
1941.1 \\
2704.0 \\
1733.9 \\
1216.3 \\
1411.3 \\
1674.6 \\
1541.2 \\
1634.2 \\
1101.1 \\
1036.2 \\
1282.7 \\
1042.9 \\
2103.1 \\
584.9 \\
643.2 \\
2279.0 \\
1239.8 \\
880.5 \\
551.5 \\
723.7 \\
832.2 \\
1018.8 \\
1088.7 \\
1400.9\end{array}$ & $\begin{array}{r}72.66 \\
200.62 \\
117.34 \\
60.04 \\
75.15 \\
106.14 \\
68.83 \\
46.64 \\
49.37 \\
58.10 \\
54.15 \\
56.05 \\
36.30 \\
36.84 \\
42.44 \\
33.45 \\
68.70 \\
18.40 \\
19.77 \\
91.74 \\
43.03 \\
28.70 \\
18.97 \\
24.25 \\
28.99 \\
34.08 \\
35.17 \\
46.37\end{array}$ & $\begin{array}{r}72.51 \\
200.62 \\
117.34 \\
59.97 \\
75.06 \\
106.02 \\
68.75 \\
46.58 \\
49.31 \\
58.03 \\
54.09 \\
55.99 \\
36.26 \\
36.80 \\
42.39 \\
33.41 \\
68.62 \\
18.33 \\
19.75 \\
91.14 \\
42.98 \\
28.67 \\
18.95 \\
24.22 \\
28.95 \\
34.04 \\
35.13 \\
46.31\end{array}$ \\
\hline
\end{tabular}


HEAT TRANSFER DATA

(Continued)

\begin{tabular}{|c|c|c|c|c|c|c|}
\hline $\begin{array}{l}\text { Ruń } \\
\text { No. }\end{array}$ & $\begin{array}{l}\text { Film } \\
\text { Temp. }\end{array}$ & $\begin{array}{l}\text { Film } \\
\text { Viscos- } \\
\text { ity } \\
z_{f}\end{array}$ & $\begin{array}{l}\text { Film } \\
\text { Viscos- } \\
\text { ity } \\
\text { Absolute } \\
\mu_{f}\end{array}$ & $Q$ & $\mathbf{h}$ & $\frac{h D}{k}$ \\
\hline nits & $F$ & $\begin{array}{l}\text { Centi- } \\
\text { poises }\end{array}$ & $\frac{\mathrm{Ibs}}{(\mathrm{hr} \cdot)(\mathrm{ft}}$ & $\begin{array}{l}\text { B.T.U. } \\
\text { per Hr. }\end{array}$ & $\begin{array}{l}\text { B.T.U. } \\
\text { per } \\
\left(h r_{*}\right)(8 \\
\left.f t_{.}\right)\left(\delta_{1}\right.\end{array}$ & None \\
\hline $\begin{array}{l}157 \\
158 \\
159 \\
160 \\
161 \\
162 \\
163 \\
164 \\
165 \\
166 \\
167 \\
168 \\
169 \\
170 \\
171 \\
172 \\
173 \\
174 \\
175\end{array}$ & $\begin{array}{l}21.392 \\
21.087 \\
20.430 \\
20.206 \\
20.040 \\
20.006 \\
20.032 \\
19.115 \\
28.578 \\
18.068 \\
18.336 \\
18.561 \\
18.864 \\
18.847 \\
18.916 \\
19.504 \\
19.747 \\
19.357 \\
19.669\end{array}$ & $\begin{array}{l}3.74 \\
3.77 \\
3.82 \\
3.84 \\
3.86 \\
3.86 \\
3.86 \\
3.94 \\
3.18 \\
4.04 \\
4.02 \\
4.00 \\
3.97 \\
3.97 \\
3.96 \\
3.90 \\
3.88 \\
3.92\end{array}$ & $\begin{array}{l}9.05 \\
9.12 \\
9.24 \\
9.29 \\
9.34 \\
9.34 \\
9.34 \\
9.54 \\
7.70 \\
9.78 \\
9.72 \\
9.67 \\
9.60 \\
9.60 \\
9.58 \\
9.45 \\
9.40 \\
9.49 \\
9.41\end{array}$ & $\begin{array}{r}1060.2 \\
786.4 \\
1069.2 \\
1217.7 \\
1143.9 \\
1741.8 \\
1864.5 \\
2177.3 \\
2299.2 \\
2186.0 \\
2088.2 \\
1804.3 \\
1633.1 \\
1295.6 \\
1036.2 \\
837.2 \\
866.6 \\
1054.8 \\
411.2\end{array}$ & $\begin{array}{r}33.27 \\
24.11 \\
54.40 \\
39.18 \\
36.49 \\
57.05 \\
70.53 \\
86.04 \\
109.43 \\
105.81 \\
107.3 .4 \\
93.43 \\
83.69 \\
58.99 \\
44.04 \\
32.70 \\
32.02 \\
37.73 \\
13.24\end{array}$ & $\begin{array}{r}33.23 \\
24.08 \\
54.34 \\
39.13 \\
36.45 \\
56.99 \\
70.45 \\
85.94 \\
109.31 \\
105.69 \\
107.02 \\
93.33 \\
83.60 \\
58.92 \\
43.90 \\
32.66 \\
31.98 \\
37.69 \\
13.1 .3\end{array}$ \\
\hline
\end{tabular}


HEA T TRANSFHR DATA (Continued)

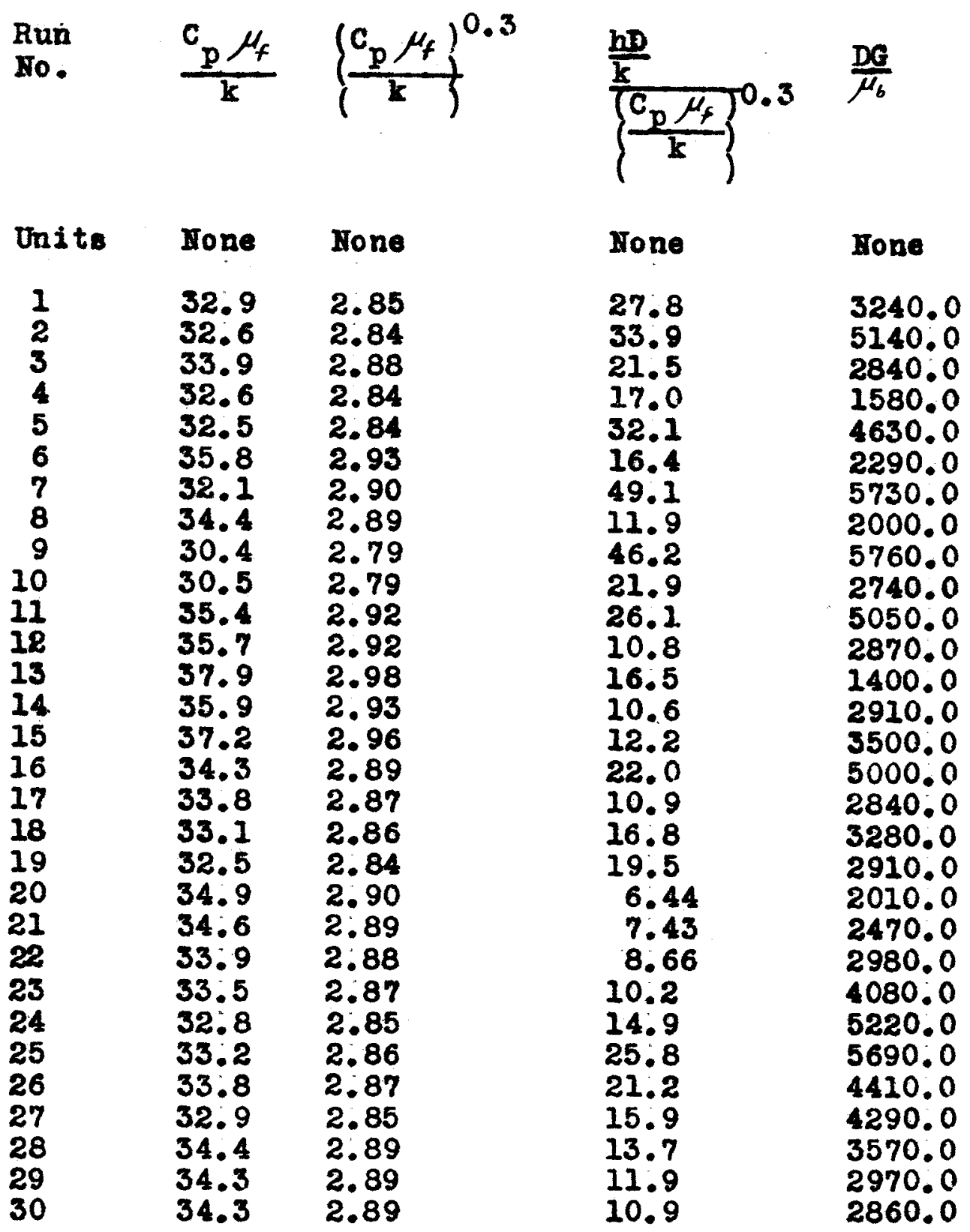


HRAT TRANSFER DATA (Continued)

Run

No.

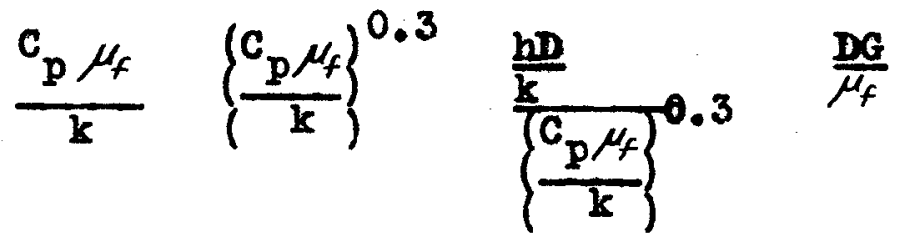

$\begin{array}{lcccc}\text { Units } & \text { None } & \text { None } & \text { None } & \text { None } \\ 31 & 34.6 & 2.89 & 8.88 & 2580.0 \\ 32 & 34.7 & 2.90 & 7.87 & 2340.0 \\ 33 & 34.6 & 2.89 & 12.2 & 5260.0 \\ 34 & 30.2 & 2.78 & 19.1 & 6090.0 \\ 35 & 30.5 & 2.79 & 54.5 & 5580.0 \\ 36 & 30.4 & 2.79 & 39.1 & 4450.0 \\ 37 & 30.2 & 2.78 & 41.8 & 4350.0 \\ 38 & 30.0 & 2.77 & 37.2 & 3370.0 \\ 39 & 29.8 & 2.77 & 21.7 & 2710.0 \\ 40 & 29.8 & 2.77 & 21.1 & 2340.0 \\ 41 & 32.6 & 2.84 & 10.8 & 1650.0 \\ 42 & 33.5 & 2.87 & 12.0 & 1980.0 \\ 43 & 33.6 & 2.87 & 12.4 & 2280.0 \\ 44 & 33.6 & 2.87 & 16.4 & 2710.0 \\ 45 & 33.8 & 2.87 & 17.5 & 2910.0 \\ 46 & 33.9 & 2.88 & 20.4 & 3120.0 \\ 47 & 33.9 & 2.88 & 21.8 & 3450.0 \\ 48 & 34.3 & 2.89 & 26.6 & 3870.0 \\ 49 & 34.3 & 2.89 & 33.9 & 4350.0 \\ 50 & 34.3 & 2.89 & 41.0 & 4490.0 \\ 51 & 34.3 & 2.89 & 52.7 & 5240.0 \\ 52 & 34.0 & 2.88 & 56.5 & 5230.0 \\ 53 & 31.8 & 2.82 & 10.3 & 1500.0 \\ 54 & 31.8 & 2.82 & 9.9 & 1770.0 \\ 55 & 31.6 & 2.82 & 13.3 & 2440.0 \\ 56 & 31.1 & 2.80 & 15.6 & 2870.0 \\ 57 & 30.9 & 2.80 & 18.4 & 3470.0 \\ 58 & 30.8 & 2.80 & 20.1 & 4000.0 \\ 59 & 30.4 & 2.79 & 28.9 & 5230.0 \\ 60 & 29.7 & 2.77 & 33.0 & 5830.0\end{array}$


HEAT TRANSFER DATA (Continued)

\begin{tabular}{|c|c|c|c|c|}
\hline $\begin{array}{l}\text { Run } \\
\text { No. }\end{array}$ & $\frac{c_{p} \mu_{f}}{k}$ & $\left\{\frac{c_{p} \mu}{k}\right.$ & $\frac{\frac{h D}{k}}{\frac{C_{n} \mu_{f}}{n}}$ & $\frac{D G}{\mu_{b}}$ \\
\hline Units & None & Hone & None & None \\
\hline $\begin{array}{l}61 \\
62 \\
63 \\
64 \\
65 \\
66 \\
67 \\
68 \\
69 \\
70 \\
71 \\
72 \\
73 \\
74 . \\
75 \\
76 \\
77 \\
78 \\
79 \\
80 \\
81 \\
82 \\
83 \\
84 \\
85 \\
86 \\
87 \\
88 \\
89 . \\
90\end{array}$ & $\begin{array}{l}32.9 \\
35.3 \\
39.7 \\
37.5 \\
35.7 \\
31.8 \\
38.2 \\
37.6 \\
37.9 \\
38.9 \\
40.7 \\
41.4 \\
46.3 \\
31.6 \\
40.4 \\
37.1 \\
35.0 \\
39.9 \\
38.5 \\
38.6 \\
40.0 \\
33.1 \\
35.3 \\
34.3 \\
39.7 \\
41.7 \\
42.9 \\
43.8 \\
35.4 \\
37.4\end{array}$ & $\begin{array}{l}2.85 \\
2.92 \\
3.02 \\
2.97 \\
2.92 \\
2.82 \\
2.98 \\
2.97 \\
2.98 \\
3.00 \\
3.04 \\
3.06 \\
3.16 \\
2.82 \\
3.03 \\
2.96 \\
2.90 \\
3.02 \\
2.99 \\
2.99 \\
3.03 \\
2.06 \\
2.91 \\
2.89 \\
3.02 \\
3.06 \\
3.09 \\
3.11 \\
2.91 \\
2.96\end{array}$ & $\begin{array}{r}79.4 \\
20.7 \\
22.4 \\
33.5 \\
25.6 \\
29.1 \\
15.7 \\
13.4 \\
12.2 \\
8.4 \\
6.3 \\
19.3 \\
20.0 \\
53.9 \\
193.5 \\
35.0 \\
50.1 \\
11.3 \\
25.7 \\
14.8 \\
11.3 \\
18.8 \\
20.2 \\
13.1 \\
8.7 \\
5.5 \\
10.0 \\
12.7 \\
66.6 \\
15.9\end{array}$ & $\begin{array}{r}5320 \\
3260 \\
4450 \\
3960 \\
3570 \\
4810 \\
2690 \\
2180 \\
1670 \\
1150 \\
869 \\
3710 \\
4470 \\
5540 \\
3450 \\
3050 \\
4690 \\
2720 \\
3720 \\
1810 \\
2150 \\
2450 \\
2870 \\
2070 \\
1230 \\
1350 \\
1480 \\
1890 \\
4380 \\
802\end{array}$ \\
\hline
\end{tabular}


HEAT TRANSFER DATA (Continued)

$\operatorname{Run}_{\text {No. }} \quad \frac{c_{p} \mu_{f}}{k} \quad\left(\frac{c_{p} \mu_{f}}{k}\right)^{0.3}$

$\frac{\frac{h p}{k}}{\left(\frac{c_{p} \mu_{f}}{k}\right)^{0.3}}$

$\frac{D G}{\mu_{b}}$

91

None

Hone

None

None

34.9

2.90

20.0

1260

94

42.7

3.08

13.1

1290

95

42.7

3.08

14.2

1270

96

41: 4

$3: 06$

16.9

1900

97

$40: 7$

3.04

14.0

1750

3.06

40.0

3.03

13.4

843

98

39.3

100

40.9

101

40.7

3.01

5.5

892

3.05

15. 9

1360

3.04

20.9

1740

25.3

2720

44.1

103

46.1

3.11

3.16

12.3

2360

104.

48.9

3.21

46.1

3.16

3.5

2170

105

45.2

3.14

108

27.3

41.4

2.70

2. 06

41. 9

3.14

12.9

3210

42.9

3690

26.8

3940

109

111

42.4

3.08

21. 9

2380

16.0

10.7

1920

12.9

1540

112

43.9

3.11

10.6

45.0

3.13

9.7

8.7

23.7

27.5

23.0

1260

114

45.9

3.15

45.7

3.15

22.6

1080

43.9

3.11

18.3

14.8

993

924

3240

3280

117

45.0

3.13

2760

119

45.6

3.15

1980

45.6

3.15

$11: 8$

1610

121

45.0

3.13

9.4

1340

1110

849 
HEAT TRANGFTR DATA (Continued)

Run

No.

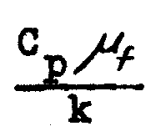

$\frac{\frac{h D}{k}}{\left(\frac{c_{p} \mu_{f}}{k}\right)^{0.3}}$

Mone

21.8

62.3

36.4

18.7

23.3

32.9

21.3

14.3

15.1

17.8

16.6

17.1

11.1

11.3

10.4

10.3

21.1

5.6

6.0

28.2

13.1

8.7

5.8

7.4

8.9

10.5

10.8

14.1
$\frac{D G}{\mu_{b}}$

None

2393.1

3729.1

2963.9

1597.5

2362.1

2514. 9

2938.6

1648.2

1826.7

1880.6

1822.4

1725.1

1498.6

1360.1

$-1151.5$

, 993.2

858.4

1107.2

1124.2

2899.6

1415.5

850.2

220.5

271.4

298.2

509.3

$793: 9$

874.9 


\section{HRAT TRAISPER DATA (Concluded)}

Run

No.

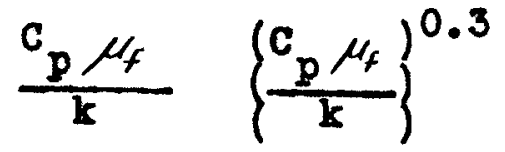

$\frac{\frac{h D}{k}}{\left(\frac{c_{p} \mu_{f}}{k}\right)^{0.3}}$

$\frac{D G}{\mu_{b}}$

$\begin{array}{lll}\text { Units } & \text { None } & \text { None } \\ 157 & 52.11 & 3.27 \\ 158 & 52.52 & 3.28 \\ 159 & 53.25 & 3.30 \\ 160 & 53.53 & 3.30 \\ 161 & 53.78 & 3.31 \\ 162 & 53.79 & 3.31 \\ 163 & 53.78 & 3.31 \\ 164 & 54.92 & 3.33 \\ 165 & 44.37 & 3.12 \\ 166 & 56.31 & 3.35 \\ 167 & 55.97 & 3.27 \\ 168 & 55.70 & 3.34 \\ 169 & 55.31 & 3.33 \\ 170 & 55.31 & 3.33 \\ 171 & 55.19 & 3.33 \\ 172 & 55.42 & 3.32 \\ 173 & 54.13 & 3.31 \\ 174 & 54.67 & 3.32 \\ 175 & 54.22 & 3.31\end{array}$

None

10.1

7.3

16.5

11.9

11.0

17.2

21.3

25.9

35.0

31.5

32.7

27.9

25.1

17.7

13.2

9.8

9.7

11.3

4.0
None

1088.5

1024.8

1252.5

1363.3

1345.8

1843.4 2672.4 3502.4 3810.9 3648.3 3622. 2 2936.3

2723.6

1991.9

1488.3

1133.6

1009.5

892.5

345.2 
viscosity was read from the curve at this temperature. The riscosities in centipoises were converted to absolute viscosities by multiplying by 2.42 .

The quantity of heat transferred per hour was calculated as the product of the temperature decrease of the test liquid, the specific heat, and the weight rate of flow per hour. The film coefficient, $h$, was calculated by means of Newton's law, $Q / O$ - h A $\Delta t$, in which $Q / O$ is the quantity of heat transferred per hour, $A$ is the heat transfer area, and $\Delta t$ is the temperature differential. In this case the area of heat transfer was taken as the inside area of the six feet test section. The logarithmic mean temperature drop was also used in this calculation.

The film coefficient, physical properties, and characteristics were used to calculate the Nusselt and Prandtl groups. The Reynolds number was calculated directly from the weight rate of flow and the bulk viscosity as $4 \pi / \pi D / \mu_{b}$.

The data of Run Ho. 61 are used in the following sample calculation: 
$\Delta t_{1}:$

$\Delta t_{2}:$

Log Yean $\Delta t$

Test Iiquid $\Delta t$

$$
+2
$$

Weight Rate of Flow

$\Delta$

$$
\begin{aligned}
\Delta t_{1} & =t_{1}-t \\
& =53.462-42.523 \\
\Delta t_{1} & =10.939^{\circ} \mathrm{F} \\
\Delta t_{2} & =t_{2}-t \\
& =50.035-42.523 \\
\Delta t_{2} & =7.510^{\circ} \mathrm{F} \\
\Delta t_{m} & =\frac{t_{1}-t_{2}}{t_{1}} \\
& =\frac{10.939-7.512}{t_{2}} \\
& 2.30310 \mathrm{~g} \frac{10.939}{7.512} \\
\Delta t_{m} & =9.117^{\circ} \mathrm{F} \\
\Delta t & =t_{1}-t_{2} \\
& =53.462-50.035 \\
\Delta t & =3.427^{\circ} \mathrm{F} .
\end{aligned}
$$

$$
\begin{aligned}
W & =\times 60 \\
& =32.88 \times 60 \\
W & =1973.0 \quad \mathrm{lbs} . / \mathrm{hr} .
\end{aligned}
$$

Average Test Iiquid

$$
\text { Temperature }
$$

$$
\begin{aligned}
t_{a} & =\left(t_{1}+t_{2}\right) / 2 \\
& =(53.462+50.035) / 2 \\
t_{a} & =51.749^{\circ} \mathrm{F} .
\end{aligned}
$$


Absolute V1800 81ty

Film Temperature

Heat Transf erred

Filn Coefficient

Iruse 1 t Kumber

$$
\begin{aligned}
& \mu=2 \times 2.42 \\
& \mu=2.23 \times 2.42 \\
& \mu_{6}=5.4016 s_{0} /\left(h x_{.}\right)\left(f t_{0}\right) \\
& \mu_{f}=2.36 \times 2.42 \\
& \mu_{f}=5.71168 . /\left(h_{0}\right)\left(f t_{0}\right) \\
& t_{f}=\left(t+t_{a}\right) / 2 \\
& -(42.523+51.749) / 2 \\
& t_{f}=47.136^{\circ} \mathrm{F} \text {. } \\
& Q=W \times \Delta t \times C_{p} \\
& =1973.0 \times 3.427 \times 0.504 \\
& Q=3408.0 \text { B.T.U. per hr. } \\
& Q=h \times A \times \Delta t_{m} \\
& h=Q /\left(A \times \Delta t_{m}\right) \\
& =3408.0 /(1.65 \times 9.117) \\
& h=226.50 \text { B.T.U./(hr.) } \\
& \left(8 q . f t_{.}\right)\left({ }^{0} \mathrm{~F} .\right) \\
& \mathrm{Nu}=\mathrm{hD} / \mathrm{k} \\
& =226.5 \times 0.0874 / 0.0875
\end{aligned}
$$$$
\mathrm{Nu}=226.30
$$

$N u=226.30$ 
Prand tl Number

$$
\begin{aligned}
\mathrm{Pr} & =\mathrm{C}_{p} \mu_{f} / \mathrm{k} \\
& =0.504 \times 5.71 / 0.875 \\
& =32.9 \\
\mathrm{Pr} 0.3 & =32.9^{0.3} \\
& =2.85
\end{aligned}
$$

Ratio of Nusselt to Prand tl Number to 0.3 power

$$
\begin{aligned}
\frac{\mathrm{hD} / \mathrm{k}}{\left(c_{p} / \mathrm{k}\right)^{0.3}} & =\frac{226.3}{2.85} \\
& =79.4
\end{aligned}
$$

Reynolds Number

$$
\begin{aligned}
\text { Re } & =(4 \times W) /\left(\pi \times D \times \mu_{1}\right) \\
& =\frac{4 \times 1973.0}{3.1416 \times 0.0874 \times 5.40}
\end{aligned}
$$

$R e=5320$

The experimental data are shown graphically by Curve II., page 65. The straight line through the pointo is an arbitrary line that seemed to best represent the median'locus. In this correlation $(\mathrm{hD} / \mathrm{k})\left(c_{\mathrm{p}} \mu_{f} / \mathrm{k}\right)^{0.3}$ 18 plotted logarithmically against $D G / \mu_{6}$. This method of plotting employ the type equation recommended by Dittus and Boelter (17). 


\section{Curve II. \\ Cooling Data Correlation}

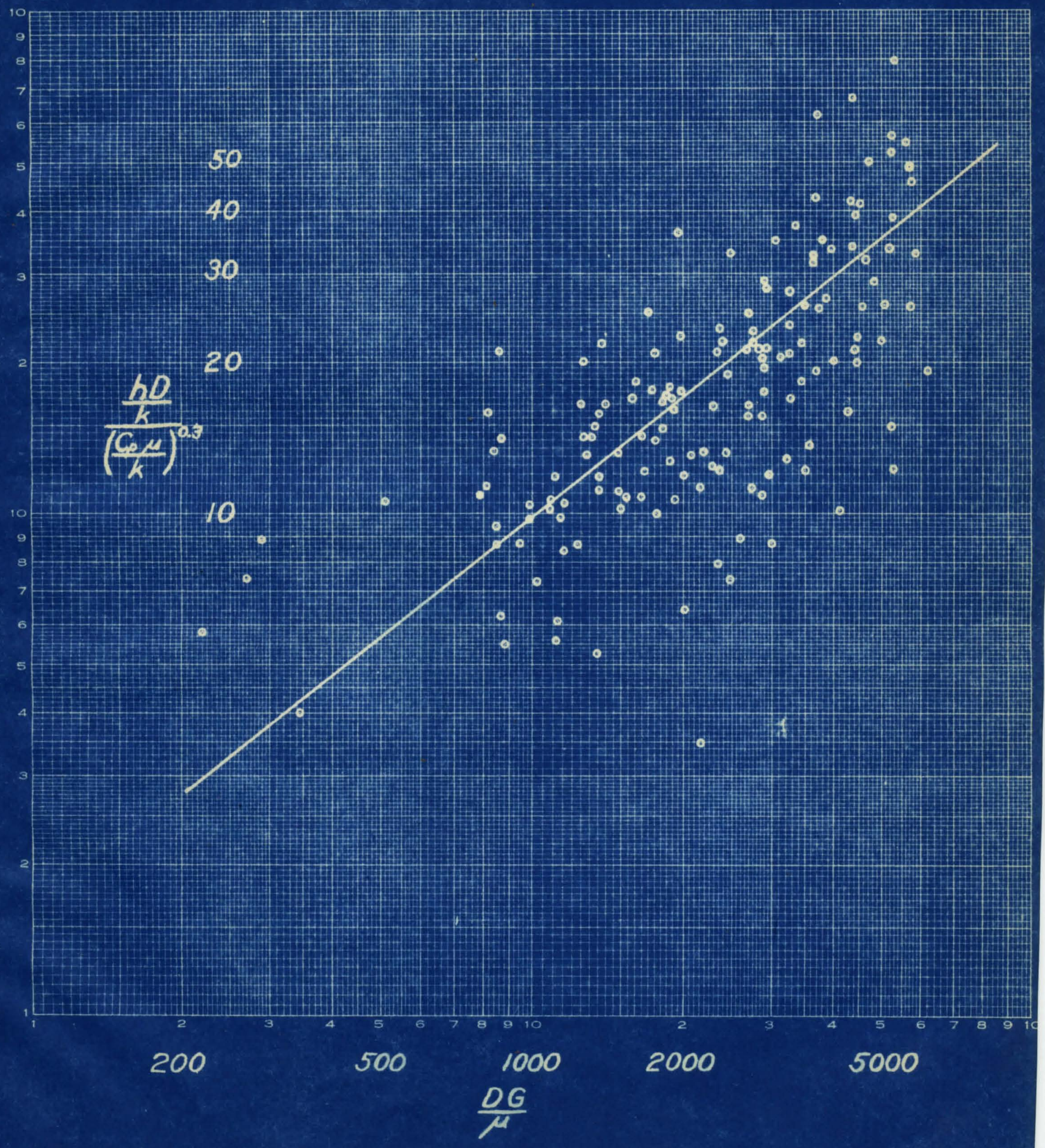


CONCLUSIONS 


\section{Curve III. \\ Grouping and Comparison of Heat Transfer Data}

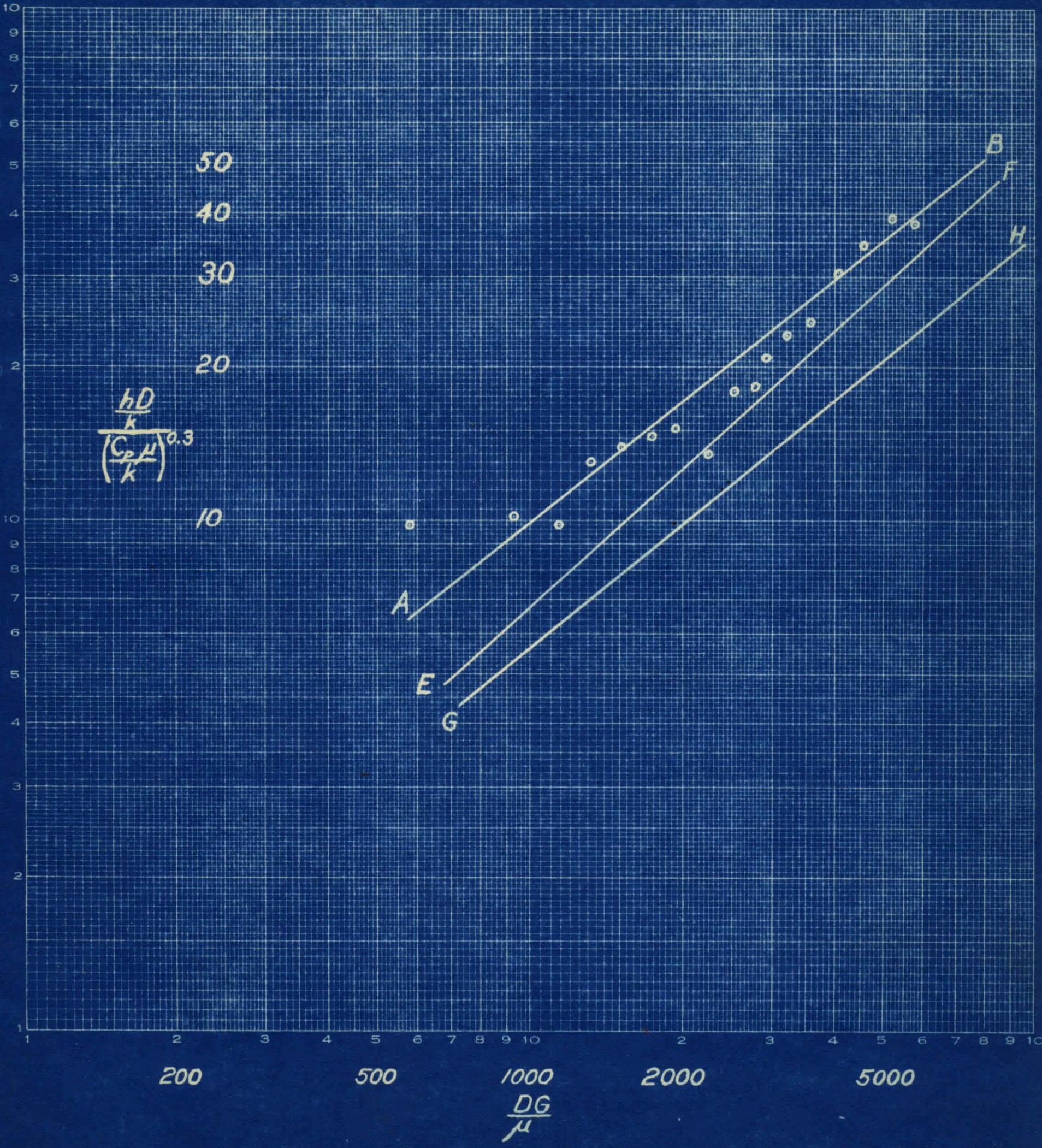


The logarithmic plot of the ratio of the Nuseelt to the Prand 1 numbers to the 0.3 power against the Reynolds number indicates that this type of equation can be uged for the correlation of cooling heat transfer data in the viscous and critical ranges.

The data of Sherwood and Petrie ${ }^{(i)}$ gave a slope to the empirical curve greater than 0.8. A plot of the first sixty runs of this data using bulk viscosity throughout the calculations gave a slope to the line of $0.915^{(17)}$. The equation of the curve representing the data in this study is as follows:

$$
\frac{h D}{k}=0.0387\left(_{\left(\frac{c}{p} \mu_{f}\right.}\right)^{0.3}\left(\frac{D G}{\mu_{b}}\right)^{0.801}
$$

This equation was obtained by grouping the data and drawing the best straight line through the points. In the grouping of the data, Reynolds numbers were collected in groups of ten beginning with the smallest and continuing through to the highest value. The line $A-B$ on Curve III., page 67, was assumed to be the best line through all the points.

A comparison with previous work is also given in Curve III., page 67. The line E-F is a plot of the equation determined by Groth (17). The line 
G-H is the plot of the equation of Dittus and Boelter (I). The three lines, $A-B, E-F$, and G-H, have slopes that are very nearly the same, and the lines are fairly close together. These facts would seem to indicate that the temperatures at which the data were taken have very little influence on the location of the curres. From the plot of the data it is indicated that the use of this type of equation is sufficiently accurate for Reynolds numbers above 1000. Below this figure the correlation is not as successful. 
The author of this thesis is indebted to Fdvard Groth, Jr.

and

$$
\text { James F. Scott }
$$

who assisted with the experimental work In this investigation 
BIBI.IOGRAPHY 
1. Sherwood, T. K., and Petrie, J. M.; Ind. Eng. Chem. . 24, 736 (1932)

2. Browne, R. Y. and Finger, F. W., Jr., Thesis in Chemical Fngineering. University of Louisville (1935)

3. Browne, R. Y., Thesis in Chemical Engineering, University of Louispille (1936)

4. Donahus, Hubert, Thesis in Chemtcal Engineering; University of Louisville (1936)

5. Colburn, A. P.; Trans Amer. Inst. Chem. Eng., 29, 174 (1933)

6. Morris, F. H., and Whitman, W. G.; Ind. Eng. Chem., 20, 234 (1928)

7. Keevil, C. S., and YcAdams, W. H.; Chem. and Met., 36, 464 (1929)

8. Colburn, A. P., and Hougen, C. A.; Ind. Eng. Chem. 22, 522 (1930)

9. Linden, C. M. and Yontizlon, G. H.; Ind. Eng. Chem., 22, 708 (1930)

10. Drew, T. B., Hogan, J. J., and YcAdams, W. H.; Ind. Ing. Chem., 23, 936 (1931)

11. Cryder, D. S., and Gilliland, E. R.; Ind. Hng. Chem. 24, 1382 (1932) 
12. Drew, T. B.; Ind. Fng. Chem., 24, 152 (1932)

13. Sherwood, T. K., and Kiley, D. D., and Mangsen,

G. E.; Ind. Eng. Chem., 24, 273 (1932)

14. Smith, T. F. D.; Trans Amer. Inst. Chem. Ing;

31,83 (1935)

15. Badger, W. I., and KcCabe, W. I.; Elemente

of Chemical Engineering, MoGraw Hill Book Company (1931)

16. Walker, H. W., Lewis, W. K., Mcadams, W. H., and Gilliland, E. R., Principles of Chemical Engineering, NoGraw Hill Book Company (1937)

17. Groth, Edward, Jr., Thesis in Chemical

Engineering, Untversity of Louigville (1937) 